The Polish Journal of the Arts and Culture. New Series 9

(1/2019): 53-91 [ARTICLE]

DOI: $10.4467 / 24506249$ PJ.19.003.11135

\title{
The formation and the development of the Arabic script from the earliest times until its standardisation
}

\section{Bożena Prochwicz-StudnickA}

\begin{abstract}
The article overviews and systematises the theories and hypotheses, in the current paleographical discourse, that refer to the beginning of the Arabic script and the paths and the causes of its development until the 1oth century, when this script was standardised. The article briefly discusses the linguistic situation in the Arabian Peninsula beginning from the 1st millennium $\mathrm{BC}$ and the issue of the diffusion of the Ancient South Arabian script in the notation of the proto-Arabic dialects. Subsequently it presents hypotheses devoted to the origin of the Arabic script and the probable paths through which the Nabataean script made its way to the Arabian Peninsula. It presents the current state of knowledge in reference to the development of the Arabic writing, the causes and the nature of the changes in the graphical form of the script. All of these elements are presented in the context of the cultural and socio-political changes which accompanied these processes in the Arabian Peninsula and in the Near East.
\end{abstract}

Keywords: Arabic script, Arabs, paleography, hijāzī, kūfì, naskhī, khatt mansūb

Bożena Prochwicz-Studnicka Ph.D. in Arabic literary studies. A researcher exploring the classical Arab-Muslim world. The author of many source text-oriented publications, the latest of which include the following: Literary representation of the self in medieval Arabic autobiographies and the cultural barriers to self-cognition. The literacy theory perspective, "Al-Qantara" (forthcoming), The Origins of the Great Significance of Writing in the Arab-Muslim Culture, "Anthropos" 113.2018/1, Ibn al-Ğawzī, "Historie bystrych umystów" (Ahbbāral-adkiyā'), "Przegląd Orientalistyczny" 1-2/2018.

E-MAIL: bozena.prochwicz-studnicka@ignatianum.edu.pl 


\section{Introduction}

The Arabic script, similarly to other Semitic writing systems, is an alphabet ${ }^{1}$ written from right to left. Each letter has four or two forms, depending on its position within a word. The letters change shape so that they can be joined within one word. A peculiar feature of the Arabic script has to do with its representation that is limited to consonants only; hence, Peter T. Daniels introduced the term $a b j a d^{2}$ as a Semitic equivalent of the Greek term alphabetos $^{3}$. Vowels are indicated by means of consonantal signs or special graphical signs. Among the 28 signs (graphemes) of the Arabic alphabet, two: g and $\checkmark$, which are used above all to indicate consonants ( "w" and "y"), are also used to represent the long vowels " $\overline{\mathrm{u}}$ " and "”, respectively, as well as diphthongs ("aw" and "ay"), whereas the grapheme I represents the long vowel "ā" 4 . Symbols which appear above or below the letters are used to indicate short vowels. They do not appear in natural texts, but merely serve auxiliary purposes. They are indicated in materials intended for Arabic language study, in publications of certain classical texts, and in individual cases, when there is a risk of misinterpreting a word. The only text which is completely vocalised is the Qur'an.

1 The origin of alphabetic writing has not been completely explained. One of the theories indicates the proto-Sinaitic script, which consists of about 30 signs (inscriptions are said to date back to about the middle of the second millennium BC) as the earliest quasi-alphabetic script, J. Danecki, Gramatyka opisowa języka arabskiego, Vol. 1, p. 132. An overview of the most important theories associated with the origin of the development of alphabetic writing in: D. Diringer, The Alphabet: A Key to the History of Mankind, pp. 195-206; I. J. Gelb, A Study of Writing, pp. 120-176.

2 Due to the problems which are discussed in the article, the ALA-LC scholarly transcription system was applied except for these Arabic terms which are well-established in the English language. Such terms are represented in simplified transcription.

3 The word abjad is an acronym of alif, b $\bar{a}$, jìm, dāl - the first four signs of the Arabic alphabet in the former sequence of letters (this system, which was inherited from earlier Semitic alphabets, takes into account the numerical significance of letters). One may apply the term consonantal alphabet (abjad) in the complete sense of the word only to the Phoenician alphabet, P. T. Daniels, The Arabic Writing System, p. 415; B. B. Powell, Writing. History and Theory of the Technology of Civilization, p. 171. For criticism associated with the introduction of the term abjad see. B. B. Powell, op. cit., pp. 172-174.

4 They also perform the function of a prop for the hamza, a sign which is not formally considered a part of the alphabet and which serves to represent a voiceless, stop, laryngeal consonant. 
The Arabic writing system developed from the Nabataean variety of the Aramaic script ${ }^{5}$ and even though we do not know precisely when this process began and how it proceeded, the first traces of the development of the Arabic script are posited at the beginning of our era. However, before this happened, other varieties of an alphabetic script were known and used in the Arabian Peninsula in the antiquity.

\section{The linguistic situation and what we know about writing in the Arabian Peninsula until the begin- ning of our era}

Knowledge of the ancient history of the Arab Peninsula is fragmentary. The Arab people appeared for the first time in the annals of the history of the Middle East through the intermediation of Assyrian sources. An account of the clash of the Assyrian King Shalmaneser III (859-825 BC) with the SyroPalestinian coalition at Qarqar, carved on the stela from Kurkh' (near Diyarbakır) dates back to $853 \mathrm{BC}$. It mentions the ruler "Gi-in-di-bu-'u [mâtu] arba-a-a" (line 94) who headed an army consisting of 1000 camels. The word arba- $a-a$ which was most likely pronounced ' $\operatorname{arb} \bar{a} y(a)$ is a relative adjective derived from the noun 'arab, hence the translation of this word is the following: "Gindibu, the Arab/Gindibu who belongs to the Arabs"6. Questions as to

5 The theory about the Nabataean origin of the Arabic script was advanced by Theodor Nöldeke in 1865 (the parallel thesis about the Syriac roots of the script was abandoned after Nabataean inscriptions with Arabic elements were discovered). It was supported by further research by Adolf Grohmann (Arabische Paläographie, Hermann Böhlaus Nachfolger, Wien 1967-1971, Band 1-2). The work of Beatrice Gruendler (The Development of the Arabic Script: From the Nabatean Era to the First Islamic Century According to Dated Texts, Scholar Press, Atlanta, Ga. 1993) supplements these works. It provides a more complete image of the development of the particular letters of the Arabic alphabet in a diachronic arrangement. The theory about the Nabataean roots of the Arabic script is currently adopted by the vast majority of researchers. In 1966 Jean Starcky returned to the 19th-century thesis about the origins of the Arabic script, pushing an opinion about the origins of the Arabic script in the Syriac cursive script used in the courts of the Lakhmid kings of Al-Hīra, J. A. Bellamy, The Arabic Alphabet, pp. 99-100; B. Gruendler, op. cit., pp. 1-3. At the end of the previous century, the hypothesis was restored by Françoise Briquel-Chatonnet, who put forward the argument about the prestige of the Syriac alphabet in the period which was crucial for the formation of the Arabic alphabet, Sh. Blair, Islamic Calligraphy, p. 71.

6 Transliteration and translation in: R. W. Rogers, Cuneiform Parallels to the Old Testament, p. 296; see also J. Restö, The Arabs in Antiquity. Their History from the Assyrians to the 
whom the term Arab referred and what the etymology of the name itself is are a source of debate ${ }^{7}$. Most likely this term referred to nomadic communities, whose significance began to rise due to the domestication of the camel in ca. $900 \mathrm{BC}^{8}$. On the account of the skills which these people acquired in terms of the raising of camels and on the account of their inherent characteristic of mobility, they could be hired by local governors in oases and in agricultural centres of the Fertile Crescent, as well as in the southern part of the Arabian Peninsula, in Yemen, as guardians, including as guardians of borders. Since the period of Tiglath Pileser III's reign (?-727 BC) the Arabs (mostly nomads from the northern regions of the Peninsula) were used by the Assyrians in the realisation of their own political and economic goals - the protection of borders (Egypt), trade routes (Syria and Palestine), and also as a police and administrative force within the empire (the main centres in Mesopotamia). After the fall of the Assyrians, the position of the Arabs as "strategic partners" was enhanced even further in the period of the Persian Achaemenids (550-330 BC). In the Achaemenid state itself, they enjoyed a certain deal of autonomy and tax privileges. In return, they reinforced the Persian army, and they were hired as guides for armies traversing the deserts.

In spite of the fact that the dominant characteristic of the population of the central and northern areas of the Arabian Peninsula was associated with nomadism, some Arab tribes represented a settled mode of life. One quasiurban centre was, for example Taymā' (the Biblical Tema). The main paths of the transcontinental trade route passed through the Taymā' oasis. The Babylonian Nabonid (556-539 BC), for reasons which are not completely known, moved to the Taymā' oasis along with his court for a period of ten years. There he erected his palace and fortifications, and made military excursions to the nearby oases ${ }^{9}$, including Dadan (the Biblical Dedan), located about 80 $\mathrm{km}$ southwest of Tayma. At the time when the Achaemenids defeated the Babylonians and conquered Egypt, the trade route which had led through Tayma was diverted through Dadan. It was here that in the early Hellenistic period, ca. $4^{\text {th }} \mathrm{c}$. BC, the merchants from the west settled, establishing their trade colonies. Over the course of time, Dadan became a centre of the

\section{Umayyads, p. 126.}

7 This subject is explored by the aforementioned work of Jan Restö.

8 Ibidem, p. 624 passim.

9 T. Bryce, The Routledge Handbook of the Peoples and Places of Ancient Western Asia. The Near East from the Early Bronze Age to the Fall of the Persian Empire, pp. 695-696; F. R. Scheck, Szlak mirry i kadzidta. Od Arabii do Rzymu - śladem antycznych kultur, pp. 145-146. 
Lihyānite kingdom which was most likely politically and economically related with the Egyptian Ptolemies. This caused the establishment of a new trade route to Egypt through the Red Sea, bypassing the northern centres ${ }^{10}$.

At the turn of the second century $\mathrm{BC}$, the Arabs increasingly began to leave desert areas (the tendency to move from the centre to more fertile areas at the edges of the Arab Peninsula and beyond was already a feature of their ancestors). In the Middle East city-states were established, which as a rule were vassal-based, including Edessa, Singara, and Hatra in Mesopotamia, Emesa and Palmyra in Syria. They developed under the pervasive influence of Hellenistic culture; not all were Arab centres par-excellence, but the Arabs constituted a numerous group ${ }^{11}$. They survived the first centuries of our era, and the Arab character of some of them prevailed for a much longer period of time ${ }^{12}$.

The end of the Hellenistic period meant that the Arabs now found themselves within the sphere of influence of the Persian Sassanians (224-651) and the Roman Empire, and, after the demise of this Empire in 395, under the sway of Byzantium. Both powers used the Arabs to manage their political affairs in the region. In this context a significant role was played above all by the states of the Ghassanids and of the Lakhmids which acted as a buffer, protecting both powers against the incursions of Arab nomads from the interior of the Peninsula. The Ghassanids came from the southern part of the Peninsula and they began to enter Syria starting from the third millennium AD. Around the 6th century they embraced monophysite Christianity and became the vassals of Byzantium control the north-western region of Arabia. The Lakhmids in turn settled in the southern part of Mesopotamia (their roots also extend as far as the southern part of the Peninsula). 'Amr Ibn 'Adī, who chose Al-Hīra to be the capital of the kingdom, was supposed to be the founder of the Lakhmid dynasty at the end of the 3 rd century AD. The Lakhmids were subordinated to the Sassanians - they protected their western borders and they participated in Persian-Byzantine wars, fighting against the Ghassanids. The majority of these people were Nestorians. The Lakhmid court in Al-Hīra, organised according to Sassanian models, was an important cultural centre in the region. A few pre-Islamic poets found their

${ }^{10}$ J. A. Bellamy, op. cit., p. 95; T. Bryce, op. cit., pp. 187-188; F. R. Scheck, op. cit., pp. 141-144.

${ }^{11}$ For more information see J. Danecki, Arabowie, pp. 34-35, 48-50; J. Restö, op. cit., pp. 408, 415, 440, passim.

${ }^{12}$ I. Shahīd, Byzantium and the Arabs in the Sixth Century, Vol. 2, Part 2. Economic, Social, and Cultural History, p. 321. 
way there. The culture of Al-Hīra was eclectic; it combined Persian and Arab, Christian and pagan elements. It was a centre of scholarship and education, which to a certain extent was to take advantage of the ability to use writing ${ }^{13}$.

From the point of view of the considerations regarding the origins of the script in the Arab Peninsula at large, one should first look towards South Arabia. From the 1st millennium BC, South Arabia saw the emergence of state organisms (that of Saba, Ma'ìn, Qatabān, 'Awsān, Haḍramawt, Himyar), some of which survived until the first centuries of our era. The development of these small states was conditioned above all by favourable climate conditions, which enabled people to assume a settled way of life and agriculture to flourish, as well as the strategic position along the caravan incense trade route which led from East Africa, and also from India toward the Mediterranean Sea basin. This in turn enabled the specialisation of the nomadic people of that area in the conduct and management of trade. The south Arabs represented a culture which was different from that represented by the Arabs who inhabited the central and northern regions of the Peninsula; they were ethnically and linguistically different from them ${ }^{14}$.

Around the 1oth c. BC South Arabia saw the development of the Ancient South Arabian script which consists of 29 consonantal signs, which was used to write the Ancient South Arabian language (ASA) ${ }^{15}$. This script made its way to the central and northern lands of the Arab Peninsula along with the merchants from the south, who established there, as was already mentioned, their trade colonies ${ }^{16}$. The South Arabian script came to be used to write the Ancient North Arabian language (ANA), i.e. the proto-Arabic dialects. The great number of stone inscriptions which were preserved demonstrates that the South Arabian Script which was used to write ANA manifested itself in a few variants which are referred to as: Dadanitic (various stages of development), Safaitic, Thamūdic and Hasaitic ${ }^{17}$.

${ }^{13}$ J. Danecki, Arabowie..., pp. 55-58. For more information about the contacts of the Ghassanids with Byzantium in the political, economic and social context see I. Shahīd, Byzantium and the Arabs in the Sixth Century, Vol. 1, Part 1. Political and Military History.

${ }^{14}$ For more information see J. Danecki, Arabowie..., pp. 25-30.

${ }^{15}$ According to the terminology developed by M. C. A. MacDonald, Reflections on the Linguistic Map of pre-Islamic Arabia, pp. 28-79.

${ }^{16}$ J. A. Bellamy, op. cit., pp. 95.

${ }^{17}$ B. Gruendler, Arabic Alphabet: Origin, p. 148. The content-related paucity of the inscriptional material which covers mainly names and genealogies precludes a reconstruction of ANA. 
The Dadanitic script (its name is derived from the Dadan oasis) was used in 5 th c. BC. -1 st c. AD. in the north-western part of the Arab Peninsula ${ }^{18}$, Safaitic (whose name is derived from Șafā) in 1 st c. BC $-3 \mathrm{rd} / 4^{\text {th }} \mathrm{c}$. AD in south-western areas from Damascus and the north-eastern areas from Jabal al-'Arab. The term "Thamūdic" (derived from the Thamūd people) refers to a number of variants of the Ancient South Arabian script (which are indicated by letters - A to E) used between 6th c. BC and 4 th c. AD in many areas of the northern and central part of the Arab Peninsula. The Hasaitic variant (whose name is derived from the Al-Hasā oasis) was used between the $5^{\text {th }}$ and and c. BC in the western coast of the Persian Gulf ${ }^{19}$. Only about forty Hasaitic inscriptions have been preserved, mainly on funerary stones/epitaphs; the language of the inscriptions is vague, although it is assumed that the language in question is one of the proto-Arabic languages. We know little about the development of the script and about its users themselves ${ }^{20}$. Dadanitic (or, more broadly, ONA) was an alphabet that was used by settled literate people; Safaitic and the Thamūdic scripts are represented to the greatest extent by graffiti inscriptions which contain proper names, sometimes genealogical information, which must have been written mainly by nomads ${ }^{21}$. These instances of graffiti could have emerged in a non-literate community; they do not manifest features of systematic notation, nor did they serve any practical purposes. The ability to write things down was most likely acquired through contact between the particular groups of nomads or even individuals ${ }^{22}$. In the case of nomadic people, apart from the Ancient South Arabian script, the Greek alphabet was also occasionally used in ANA notation. However, it seems that familiarity with the script was not common. Due to the distinctly

${ }^{18}$ In the context of the Dadanitic script (from the Dadan oasis) Michael C. A. MacDonald distinguishes the Taymanitic and Dumaitic scripts (from the Taymā' and Dūmā oases). The differences in the form of the letters and the orthography were so slight that in some cases it is difficult to classify the inscriptions which were preserved to a particular script (variant). Hence one also suggested the term Oasis North Arabian scripts (ONA), M. C. A. MacDonald, op. cit., p. 32, 33 .

${ }^{19}$ Ibidem, p. 32, 33, 35 .

${ }^{20}$ B. Overlaet, M. MacDonald, P. Stein, An Aramaic-Hasaitic bilingual inscription from a monumental tomb at Mleiha, Sharjah, UAE, p. 130; M. C. A. MacDonald, op. cit., pp. 35-36. The corpus of the extant Hasaitic inscriptions in: A. Sima, Die hasaitischen Inschriften, pp. 167-200.

${ }^{21}$ M. C. A. MacDonald, Literacy in an Oral Environment, p. 76.

${ }^{22}$ These suppositions result from an analysis of the nature of the inscriptions, their content, the material that was used and the legitimacy of the use of the script in the context of nomadic way of life, ibidem, pp. 71-80. 
limited use of writing, due to the lack of writing materials other than stone, and superfluous to day-to-day requirements, the script did not play a significant role among the Arab nomads in their social and cultural lives ${ }^{23}$. In contact with settled people, the knowledge of the script (Safa'itic or Thamūdic) was useless in the majority of cases, because the settled people used the Dadanitic script (or, broadly speaking, ONA), although due to the strong Hellenisation and Aramaisation of the northern edges of the Arab Peninsula in particular, they could have also used the Aramaic and Greek scripts (familiarity with the Aramaic and Greek language did not always entail the ability to write in those languages) ${ }^{24}$. The extent of the use of a script by the settled population was limited above all to practical (economic) purposes.

The northern Arabs, both settled and nomadic, also spoke Old Arabic, i.e. pre-Islamic dialects which varied locally, and which directly preceded the development of Classical Arabic and its dialects. We know little about this language (the first extant inscriptions bearing features of Arabic date back to the late 1st $\mathrm{c}$. BC, although the language in question must have had a more extensive history $)^{25}$. It seems that, until the 6th c. AD, the Old Arabic dialects were basically represented by an exclusively spoken form. It was possible that texts were written in an Old Arabic dialect. At that time it was not the South Arabian script that was used but a script associated with other languages that were important in a given region. It is here that the history of the development of the Arabic script begins, a script for which the system of writing that was used by the Nabataeans was crucial. One may discern this in the few inscriptions that were preserved ${ }^{26}$.

For the Nabataeans, the written language was a variety of the Aramaic script $^{27}$, but it was most likely inconsistent, manifesting regional

${ }_{23}^{23}$ M. C. A. MacDonald, Reflections ..., p. 58; idem, Literacy ..., pp. 71-72.

${ }^{24}$ Idem, Literacy ..., pp. 91-92.

${ }^{25}$ M. C. A. MacDonald, Reflections ..., pp. 48-49.

${ }^{26}$ From the extant 'pure' Old Arabic inscriptions which will be discussed, inscriptions may be distinguished that were written in a different language but in which features of Arabic may be discerned (Dadano-Arabic, Aramaeo-Arabic etc.), ibidem, pp. 50-57.

${ }^{27}$ In the second half of the 1st millennium, the Aramaic language became a lingua franca of the Middle East, and the Aramaic alphabet was the most common alphabet in the region (in the Persian empire the Aramaic language and script enjoyed official status). After the fall of the empire, the official Aramaic language began to split into minor dialects, and the Aramaic script developed separate variants, including ones which were used by other Semitic languages. One such variety was the Nabataean script, J. F. Healey, The Early Alphabet, p. 42; B. Gruendler, Arabic Alphabet..., p. 149, D. Diringer, op. cit., p. 266. 
variation $^{28}$ (the artefacts of the written language of the Nabataeans date back to the early 1 st $\mathrm{c} . \mathrm{BC}-5^{\text {th }} \mathrm{c} . \mathrm{AD}^{29}$ ). The Roman conquest of the Nabataean state in 106 did not nullify the significance of the old script. It is thought to have been used by the northern Arabs until the $4^{\text {th }}$ century, with the simultaneous gradual abandonment of the South Arabian script ${ }^{30}$. It was the Nabataean variety of the Aramaic script that is supposed to have given rise to the Arabic script.

\section{The origin of the Arabic script. The development of Arabic writing}

The transition from the Nabataean to the Arabic script is a complex process and it has not been completely reconstructed due to the lack of source data. The oldest extant monument of writing in the Nabataean alphabet with elements of Arabic is an inscription from ' $\bar{E}$ n Avdat (the Negev), dated to 88/9 and $125 / 6^{31}$. The second monument chronology-wise is an Arabic inscription from An-Namāra ${ }^{32}$ (southeast of Damascus), most probably in one of the Old Arabic dialects, dated to 328 , written in the Nabataean script [Fig. 1, 2]. It is an epitaph of King Imru' al-Qays, probably the second ruler of the Lakhmids ${ }^{33}$. The inscription from An-Namāra constitutes the oldest extant evidence of the introduction of the Nabataean script to the Arabic alphabet. This inscription manifests the lām-alif ligature which is typical of the Arabic script, and the

${ }^{28}$ M. C. A. MacDonald, Reflections ..., p. 47; B. Gruendler, Arabic Alphabet..., p. 150.

${ }^{29}$ From ca. the third millennium AD, apart from the inscriptions in "classical" Nabataean script there emerged (Nabatean) inscriptions in which the graphical form of some letters underwent changes. The script of these inscriptions indicates, in a working manner, a transition between the Nabataean and the Arabic script, L. Nehmé, A Glimpse of the Development of the Nabatean Script into Arabic Based on Old and New Epigraphic Material, pp. 47-48.

${ }^{30}$ J. A. Bellamy, op. cit., p. 96; B. Gruendler, Arabic Alphabet..., p. 149.

${ }^{31}$ For more information see D. Testen, On the Arabic of the 'En 'Avdat Inscription, pp. 281-292.

${ }^{32}$ The external walls of the Nabatean temple in Jabal Ramm (ca. $50 \mathrm{~km}$ east of Akaba) feature preserved graffiti from the early 4 th century, where the script seems to represent a transition phase between Nabataean and Arabic, but due to the difficulty associated with the interpretation of the inscription, in the current state of research the identification of this language is a risky undertaking, M. C. A. MacDonald, Reflections..., p. 76, footnote 171. See the suggested interpretation of the inscription in J. A. Bellamy, Two Pre-Islamic Arabic Inscriptions Revised: Jabal Ramm and Umm al-fimāl, pp. 370-372.

${ }^{33}$ For more information see J. A. Bellamy, A New Reading of the Namärah Inscription, pp. 31-51. 
linking between letters. Further inscriptions already date back to the 6th century. These include: a trilingual Greek-Syriac-Arabic inscription in the martyrium in Zebed (southeast of Aleppo), dated to 512, a historical inscription from Jabal Usays from 528 (southeast of Damascus) ${ }^{34}$ and the Greek-Arabic inscription in the martyrium in Harrān in Lejā of $568^{35}$. It is the 6th (or 5 th) century to which the creation of a non-dated stone inscription found in the so-called "double church" in Umm al-Jimāl (northeast of Amman) ${ }^{36}$ is dated. These texts contained a great deal of homographs. Moreover, the number of graphemes was reduced from 22, which was represented by the Nabatean alphabet, to 18 . It is assumed that the period between the 4 th and 6th century was crucial for the development of the Arabic script, although the enhancement itself of the notation and the introduction of orthographical principles was a subsequent matter.

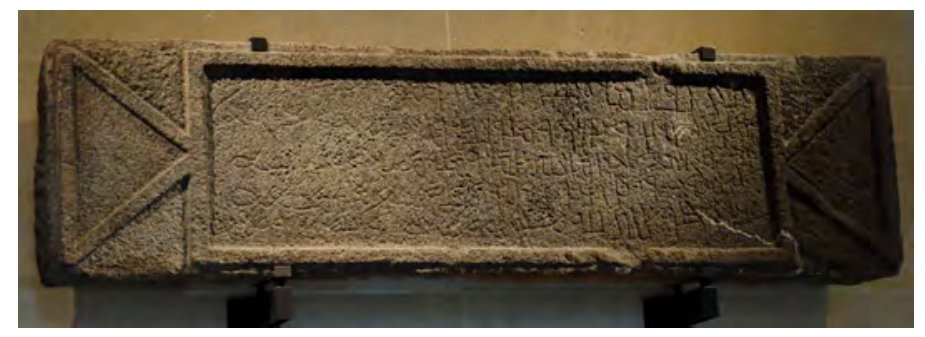

Figure 1: Arabic epitaph of Imru al-Qays, inscribed in the Nabataean script, An-Namāra. Current location: Louvre Museum, Department of Oriental Antiquities. Source: https://commons.wikimedia.org/wiki/File:Epitaph_Imru-lQays_Louvre_AO4083.jpg (access: April 2019)

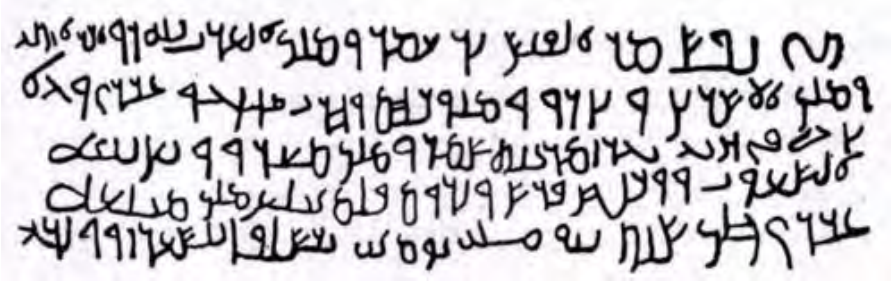

Figure 2: Text of the epitaph from Fig. 1.

\footnotetext{
${ }^{34}$ I. Shahīd, Byzantium and the Arabs in the Sixth Century, Vol. 1, Part 1. Political..., pp. 117-124. ${ }^{35}$ M. C. A. MacDonald, Literacy ..., p. 98.

${ }^{36}$ Initially the inscription was interpreted on the basis of its supposed Christian origin. J. A. Bellamy (Two Pre-Islamic Arabic Inscriptions..., pp. 372-378) suggested a different interpretation of the inscription, pointing out its anterior origin (5th c.) in reference to the establishment of the church.
} 
It is not clear which paths the Nabatean script took to reach the Arab Peninsula. There are two principal hypotheses: one indicates the caravan route linking Mecca with Syria, and therefore it stipulates that the trade contacts of the Arabs (mainly Mecca Arabs) and the Nabateans motivated the development of the script. The second hypothesis indicates Mesopotamia and the Lakhmid Al-Hira as the crucial centre for the development of the script ${ }^{37}$. If the suppositions which link Imru' al-Qays from the inscription of An-Namāra with the Lakhmids turn out to be true, then the Lakhmid court of that time could be considered the place where the Nabatean alphabet was used to write the Arabic language ${ }^{38}$.

Even though the problem of the direction in which the script reached the region, i.e. the Syrian path or the Iraq path, continues to be debated, the majority of researchers emphasise the role of the Christian communities in the development of Arabic writing, especially the role of Christian missionaries. This was supposed to be indicated by not only the Christian nature of the inscriptions which are preserved ${ }^{39}$, but by the argument, introduced by analogy which underpins the existence of Bible translations (or at least fragments of the Bible) into Arabic ${ }^{4^{\circ}}$. Christians began to reach the Arab Peninsula starting from the second century. In the course of time they were

${ }^{37}$ For example, Nabia Abott perceived the (Nabataean) origins of the Arabic script in Syria, in the An-Namāra region, Umm al-Jimāl, Jabal Usays and Harrān. According to this scholar, it was there that two branches of the script - the Syriac and the Iraq writing systems (the terms are derived from the paths which the branches of the script took to reach the Peninsula) are supposed to have developed at around the same time and met in Yathrib (Medina). Due to the severe lack of source materials, this hypothesis cannot be confirmed, N. Abott, The Rise of the North Arabic Script and its Kur'ānic Development, with a Full Description of the Kur'ān Manuscripts in the Oriental Institute, pp. 5-14; J. A. Bellamy, The Arabic Alphabet..., pp. $100-101$.

${ }^{38}$ M. C. A. Macdonald, Reflections ..., p. 59; J. A. Bellamy, The Arabic Alphabet..., p. 99; B. Gruendler, The Development ..., pp. 1-3; Peter T. Daniels, op. cit., p. 422.

${ }^{39}$ Apart from the previously mentioned inscriptions there was also supposed to be an inscription on a plaque in a church near Al-Hīra, whose wording is related by Abū 'Ubayd al-Bakrī

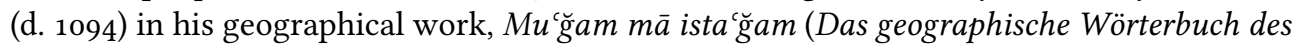
Abu 'Obeid 'Abdallah ben 'Abd el-'Aziz el-Bekri), hrsg. von F. Wüstenfeld, Johann Wolfgang Goethe-Universität Frankfurt am Mein, Göttingen 1876, Band 1, p. 364, secundum: Krzysztof Kościelniak, Chrześcijańskie piśmiennictwo arabskie przed Mahometem i jego wptyw na islam, p. 337 .

$4^{\circ}$ A. Baumstark, Das Problem eines vorislamischen christlisch-arabischen Sriftmus in arabischer Sprache, "Islamica" 4 (1931), pp. 562-575, after: G. Schoeler, The Genesis of Literature in Islam. From the Aural to the Read, pp. 24-25; also K. Kościelniak, op. cit., pp. 338-339. 
present not only at the edges of the Peninsula but also in its central parts ${ }^{41}$. A common practice of the Christian missionaries (especially in the East) was associated with the translation of at least fragments of the Gospel into local languages. Although no such translation into Arabic was preserved, according to Krzysztof Kościelniak ${ }^{42}$ :

Such pragmatics may be discerned on the example of the Evangelisation of the Goths, Egyptians, Arameans, Armenians, Abyssinians and among the people who were converted by Nestorians in Asia. It seems that this analogy is completely convincing, for otherwise one should account for the fact why the Christian missionaries applied a completely different method in the case of Arabs, the closest neighbours of Palestine.

In conclusion, the Christian missionaries, especially those who operated at the edges of the Peninsula, among the Ghassanids and Lakhmids, translating the Bible, could have initiated or accelerated the process of the transformation of the Nabataean script and of the adoption of this script to the native language of the Christian Arabs ${ }^{43}$.

It is difficult to reconstruct the process of the early formation of the Arabic script due to the lack of a sufficient number of extant documents and inscriptions. Therefore, there is no unequivocal answer to the question about the extent to which the Arabic script could have been used by the northern Arabs to write the Old Arabic language in pre-Islamic times, on the eve of the Prophet Muhammad's appearance. References to this are featured in Arabic sources, inter alia in pre-Islamic poetry, in the biography of the Prophet ${ }^{44}$, in the Qur'an and in early historiographical works ${ }^{45}$. According

${ }_{41}$ S. H. Griffith, Christians and Christianity, pp. 307-310; Gh. Osman, Pre-Islamic Arab Converts to Christianity in Mecca and Medina: An Investigation into the Arabic Sources, pp. 67-80 (especially 75-76).

$4^{2}$ K. Kościelniak, op. cit., p. 338.

${ }^{43}$ Not everyone subscribes to this idea, see. e.g. G. Graf, Geschichte des christlischen arabischen Literatur, Band 1, pp. 27-52.

44 Poetry came to be written down by Arab philologists only in the century which followed the appearance of the Prophet; the earliest biography (which is not preserved in the original version) was created at around the same time.

45 These sources are mentioned by G. Schoeler, op. cit., pp. 16-17 and A. Jones, The Word Made Visible: Arabic Script and the Committing of the Qur'an to Writing, pp. 1-16. 
to Ibn an-Nadìm (d. 385/995) ${ }^{46}$, the library of caliph Al-Ma'mūn (197-218/ 813-833) was supposed to hold a parchment which related that a certain Himyarite from Sana had a debt of 1,00o silver coins contracted from the grandfather of the Prophet Muhammad, 'Abd al-Mutțalib"

According to a Muslim tradition, it was already during the Prophet's lifetime that fragments of the revelation were written down on palm leaves, bones, fragments of skin or flat stones. The Qur'an itself mentions various accessories associated with the act of writing: qalam, raqq, qirțās, sijill, lawh, șuhuf, zubur, midād etc. ${ }^{8}$ One of the crucial words which appear in the Qur'an are based on the $k-t-b$ root. Obviously not all uses of words based on this root refer to writing/notation in the literal meaning of this word, but we do find them in many Quranic passages. The order to provide a written record (kataba), through the intermediation of a scribe (kātib), of information about the contracting of a debt (2:282) or the drawing up of a document $(k i t a \bar{b})$ which bestowed freedom to a slave ${ }^{49}(24: 33)$ are some of the many examples of this kind ${ }^{50}$.

Also the biography of the Prophet provides examples of the application of writing. Ibn Hishām (d. ca. 218/833) provided in it the text of the Constitution of Medina (Kitāb min Muhammad an-nabì $)^{51}$, which was a contract between the Prophet Muhammad and the inhabitants of Medina: muhājirs, anșārs and Jews. The constitution was supposed to define their mutual laws and obligations. The biography of the Prophet is also a source of information about the letters that he wrote ${ }^{52}$, including the information about a letter with ordinances which refer the setting of an ambush in the Nakhla oasis against a Mecca caravan in 2/624, a letter which was supposed to have been received by 'Abd Allāh Ibn Jaḥsh (the brother of Zaynab Ibn Jaḥsh, who later became a wife of the Prophet) from Muhammad ${ }^{53}$. Finally, a peace treaty with

$4^{6}$ The article adopts the following dating after the emergence of Islam - first according to the lunar Muslim calendar (Anno Hegirae), second according to our calendar (Anno Domini).

${ }^{47}$ B. Dodge, The Fihrist of al-Nadim. A Tenth-Century Survey of Muslim Culture, Vol. 1, p. 9.

${ }^{4}$ See H. E. Kassis, Concordance to the Quran, s.v.

${ }^{49}$ The document in question may be a marriage contract (for a slave), A. Jones, op. cit., p. 15.

${ }^{50}$ H. E. Kassis, op. cit., s.v. $k-t-b$; for more information see. A. Jones, op. cit., pp. 7-15; A. Jones, Orality and Writing in Arabia, pp. 591-593.

${ }^{51}$ Ibn Hishām's version is not the only extant version, see. M. Lecker, The "Constitution of Medina”. Muhammad's First Legal Document, pp. 5-26.

${ }^{2}$ If we assume that the Prophet Muhammad was illiterate, one ought to assume that the text was committed to writing by a person who could write.

${ }^{53}$ A. Jones, The Word Made Visible ... , pp. 5-7. 
Al-Hudaybiyya (6/628), under which the right of the Muslims to undertake a pilgrimage to Mecca and to conduct affairs outside Mecca was recognised, was also thought to have appeared in the written form ${ }^{54}$.

Even if not all documents mentioned in Arab sources actually existed, the fact that they were mentioned in an Old Arabic context indicates not only the awareness of the existence of a script but also the ability to use it in certain communities and in certain situations. Those who specialised in the use of the script, employed it for practical purposes, associated with certain elements of day-to-day life (e.g. in trade transactions, political contracts, correspondence). It is assumed that the relative skill in the use of the script was peculiar above all to urban centres, although it must have been very limited quantitatively. Such use of notation could have existed without a developed system of writing 55 .

Written documents are thought to have been usually kept in private homes, and they were also attached to a sword or inserted into its sheath ${ }^{56}$. The texts of important contracts, and at least those which were written down in Mecca, were kept in Al-Ka'ba, which was a reference to an ancient, not only eastern, tradition of placing documents in special places such as temples, or archives, which emphasised the importance and the significance of the documents themselves ${ }^{57}$. The transmission of cultural content in turn (poetry, proverbs, genealogies, samar stories etc.) was conducted in oral form ${ }^{58}$.

To sum up, according to internal sources, in the principal urban centres of Al-Hijāz, Mecca and Medina, writing is supposed to have been used as an instrument of transmission only for practical purposes, associated with dayto-day life. Were any artefacts of writing of that period, constituting material evidence thereof, preserved?

\section{The Hijāzī script and its standardisation}

There is a lack of complete artefacts of writing from the first two centuries of the Hijra (7th-8th century); the earliest ones, the papyrus, parchment and

${ }^{54}$ G. Schoeler, op. cit., p. 17; A. Jones, The Word Made Visible ..., p. 7.

${ }^{55} \mathrm{~J}$. Goody, The Logic of Writing and the Organization of Society, pp. 94-95.

${ }^{56}$ G. Schoeler, op. cit., p. 17.

${ }^{57}$ Ibidem, p. 18.

${ }^{58}$ A. Jones, Orality ..., p. 591; idem, The Word Made Visible ..., pp. 3-4; M. C. A. Macdonald, Ancient Arabia and the written word, pp. 21-22. 
paper ones, date back to the first half of the $3 \mathrm{rd} / 9$ th century. However, single documents written on papyrus and parchment, and fragments of longer texts, including the Qur'an in particular, and single inscriptions on stone were preserved ${ }^{59}$. Analysis of these materials indicates a likely two-directional development of the Arabic script (where a quasi-cursive script was used for practical purposes, whereas a more monumental notation was developing as a memory aid for a culture that was transmitted orally). ${ }^{60}$

The earliest extant papyrus documents of 22/642-3 are two texts: an Arabic-language text (Papyrus Berolinensis 15002) and a bilingual GreekArabic text (PERF 558). The latter is a sort of a receipt, issued for an Arab officer in Ahnas (Upper Egypt), which confirms that he received 65 sheep. The Arabic text features diacritical marks for six letters (jim $\underline{h} \underline{h} \bar{a}, \underline{d} \bar{a} l, z \bar{a} y$, shin, $n \bar{u} n)$, although in the whole text these letters, including the remaining ones, are also featured without diacritical marks ${ }^{61}$. The notation partially introduces long vowels and a few instances of alif maqșūra ${ }^{62}$. P. Berol. Papyrus 15002 seems to be a tax payment order, but it was not preserved in its entirety (three incomplete lines of text). The papyrus did not attract much attention on the part of researchers due to its fragmentary nature, although it seems that the presence of a diacritical mark for the letter nün is relevant to the subject which we are now exploring. The script of both of these documents manifests a tendency toward a cursive writing system ${ }^{63}$. According to Beatrice Gruendler, PERF 558 is an example of a "relatively developed cursive", which is testimony to the idea that the impulse for its development must have occurred a few decades earlier ${ }^{64}$.

${ }^{59}$ P. M. Sijpesteijn, Paleography, pp. 516-517. An elenchus of the earliest artefacts of Arabic writing is provided in: Y. Ragheb, Les premiers documents arabes de l'ère musulmane, pp. 679-726. In reference to the earliest graffiti see. F. Imbert, L'Islam des pierres: l'expression de la foi dans les graffiti arabes des premiers siècles, pp. 57-78.

${ }^{60}$ Sh. Blair, op. cit., pp. 143-144; A. Jones, The Word Made Visible..., pp. 3-4; idem, Orality and Writing..., pp. 591.

${ }^{61}$ I.e. the diacritical marks in the form of dots placed above and under letters which enable the distinguishing of homographs which indicate various phonemes (Arab. $i^{\prime} j \bar{a} m$ - "the removal of an impediment [in writing] by means of dots/diacritical points").

${ }^{62}$ For a more comprehensive treatment see A. Jones, The Dotting of a Script and the Dating of an Era: The Strange Neglect of PERF 558, pp. 95-103.

${ }^{63}$ P. M. Sijpesteijn, op. cit., p. 517. See below for a discussion of the understanding of the term "cursive" in the context of the Arabic script.

${ }^{64}$ B. Gruendler, The Development ..., p. 137. The earliest example of the use of diacritical marks ( $i$ j jām) is the one-word Arabic inscription on a charred piece of wood found among the Greek collection of papyri in a Byzantine church in Petra. An archeological and paleographical 
The earliest dated inscription is the so-called inscription of Zuhayr it dates back to $24 / 644$ and it has the form of double graffiti engraved on a rock in $\mathrm{Q}^{\mathrm{c}} \mathrm{c}$ al-Mu'tadil (north-western part of present-day Saudi Arabia). It features diacritical marks for the following letters: $t \bar{a}^{\prime}, z \bar{a} y, \sin , f \bar{a}^{\prime}$ oraz $n \bar{u} n^{65}$.

Finally, the earliest extant fragments of the Qur'an date back to ca. the mid-1st/late 7 th century. The necessity to preserve its content arose after the death of the Prophet. On the one hand, there was a perceived risk of distorting Muhammad's message, which could have brought about the disintegration of the umma. On the other hand, the content of the revelation was at risk of being lost due to the death of reliable messengers among the closest entourage of the Prophet, incurred in military campaigns. The presence of holy writings in Christian and Jewish communities in the Arabian Peninsula could have exerted a certain psychological pressure upon the nascent umma to commit the revelations received by Muhammad to writing. The Muslim tradition itself features references that they were committed to writing on palm leaves, flat bones and clay fragments of vessels on the initiative of the Prophet's companions. The canonical version of the Qur'an, according to the Muslim tradition, was created on the initiative of the third Rightly Guided Caliph 'Uthmān (23-35/644-655). It was based on the first compilation which at that time was in the possession of Hafșa, a daughter of the second Rightly Guided caliph, 'Umar (13-23/634-644). The work took five years and it was completed around $31 / 651^{66}$. The copies of the Qur'an were sent to the principal cities of the caliphate of that time: Medina, Mecca, Kufa, Basra and Damascus.

The early copies of the Qur'an were developed in the form of a codex (muṣhaf, pl.: mașāhif), although scrolls were also common (in contradistinction to the Jewish tradition, the Qur'anic scroll had the form of a rotulus -

analysis set the date of origin of the inscription to between the third decade of the 6th century and the beginning of the 7 th century. For a more comprehensive treatment see O. Al-Ghul, Early Inscription from Petra Carrying Diacritic Marks, pp. 105-118.

${ }^{65}$ For a more comprehensive treatment see 'A. I. I. Ghabbān, R. Hoyland, The Inscription of Zuhayr, the Oldest Islamic Inscription (24 AH/AD 644-645), the Rise of the Arabic Script and the Nature of the Early Islamic State, s. 210-237.

${ }^{66}$ On the basis of research in the copies of the Qur'an found in the great mosque in Sana in the 1970s, and the few artefacts (receipts, coins, inscriptions), a hypothesis was formulated which moves the period of the establishment of the final version of the Qur'an to the 3 rd/9th century, H. C. G. von Bothmer, K. H. Ohlig, G. R. Puin, Neue Wege der Koranforschung, pp. $33-46$. 
unwound vertically $)^{67}$. The earliest extant fragments of the Qur'an represent unique parchment palimpsests with the original text of the Qur'an in the pre-Utmān version, on which an 'Uțmān version is written over, most likely dating back to the end of the 1 st / 7 th century or the beginning of the century that followed. The script that is applied there is similar to the one used in the earliest papyri and stone inscriptions ${ }^{68}$.

These are the first artefacts of writing. In the paleographical and epigraphical discourse this script came to be known as Hijāzì (khațt hijāzī). The name covered the earliest forms of writing used in Mecca and Medina. The Mecca and the Medina scripts were laconically mentioned by Ibn an-Nadim. According to him, the first script that was used by the Arabs was the Mecca script (i.e. the script used in Mecca), then the Medina script (i.e. one which was transferred to the Medina context), and finally the Basra and the Kufic script (i.e. transferred to Basra and Kufa as the boundaries of the empire expanded $)^{69}$.

The term "Hijāzi script" actually covered a few varieties used until the beginning of the $2 \mathrm{nd} / 8$ th century ${ }^{70}$. Apart from the variation in the orthography (which could be a result of the still initial stage of the script's development, the lack of a refined canon and the variety of materials used), one may discern a few peculiar features: 1) lack of standardisation - in the Hijāzī script one could notice a certain pervasive randomness, 2) a tendency toward elongated ligatures between letters and toward the preservation of space between letters in stand-alone form, 3) slanting of the individual stems

${ }^{67}$ The earliest written records of the Qur'anic texts were made on parchment (papyrus was used as a writing material only in the case of "extracts" from the Qur'an for private use). Copies of the Qur'an were made on paper starting from the $4^{\text {th/1oth }}$ century, A. Gacek, Arabic Manuscripts. A Vademecum for Readers, p. 216; J. M. Bloom, Moving Words, p. 145.

${ }^{68}$ I.e. a part of the collection which was found in Sana from 1972 which includes a dozen or so out of thousands of fragments of the Qur'an, written on parchment (the remaining texts constitute about $1 \%$ of the entire find), which represent 926 different manuscripts of the texts which date back to the first few centuries of Islam. The earliest ones, in the form of a palimpsest, are known as the Șan'ā' I codex, see B. Sadeghi, M. Goudarzi, Șan 'ā' I and the Origins of the Qur'ān, pp. 1-129; B. Sadeghi, U. Bergmann, The Codex of a Companion of the Prophet and the Qur'ān of the Prophet, pp. 343-436.

${ }^{69}$ B. Dodge, op. cit., Vol. 1, p. 10; 'A. I. I. Ghabbān, R. Hoyland, op. cit., pp. 222-223.

${ }^{70}$ An elenchus of the extant documents and inscriptions from the 1st/7th century in the Hijāzī script in: 'A. I. I. Ghabbān, R. Hoyland, op. cit., pp. 224-225; on the subject of the early copies of the Qur'an in the Jijazi script see F. Déroche, Qur'ans of the Umayyads. A First Overview, pp. $35^{-74}$. 
of letters to the right, with alif additionally bent at the bottom of the stem (this was also mentioned by Ibn an-Nadim), 4) irregularity in the use of diacritical marks $(i j j \bar{a} m)$ 5) y $y \bar{a}$ ' has the form of a horizontal line placed beneath the letter that precedes it ${ }^{71}$ [Fig. 3].

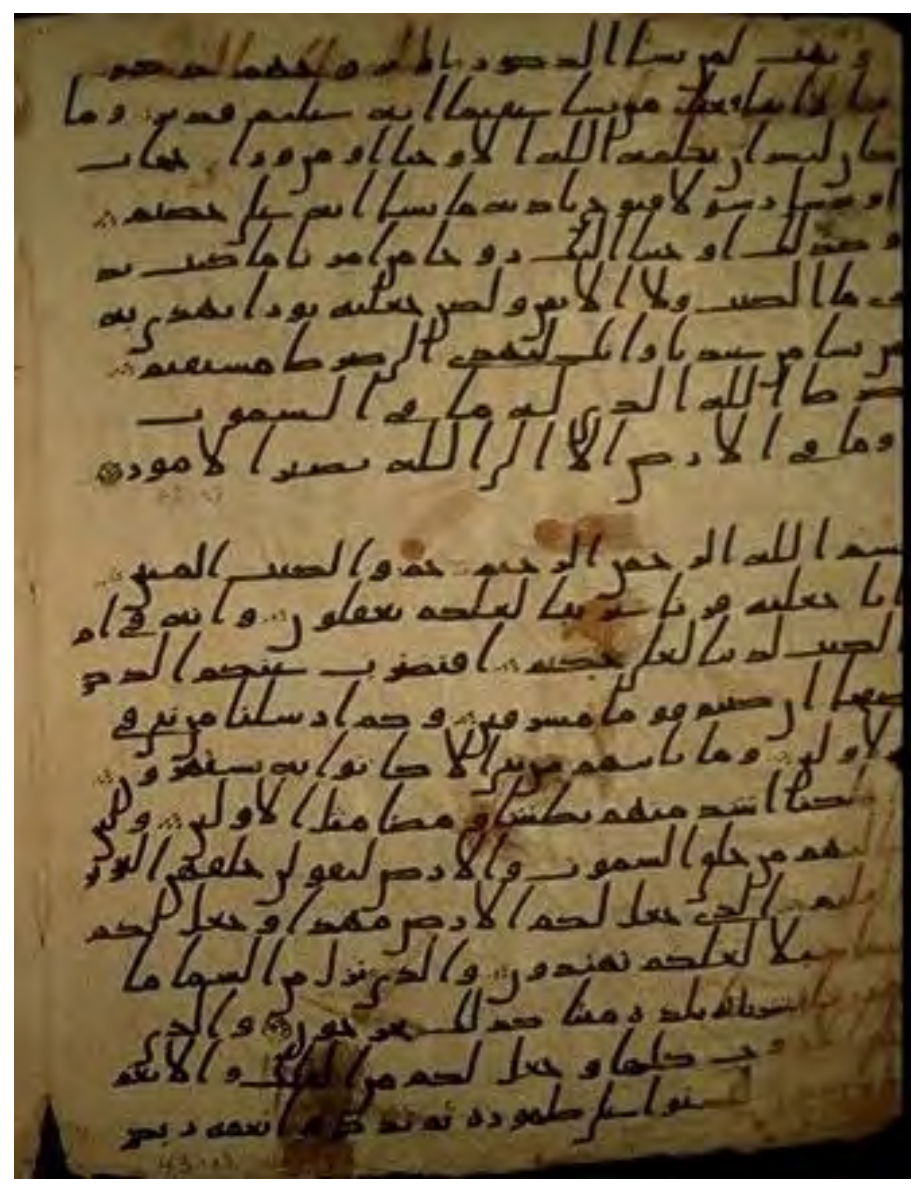

Figure 3: A folio from a Qur'ānic Manuscript (8th century) in the Hijāzī script, ink on parchment, the so-called Șan'â’ DAM 01-25.1 codex. Current location: Maktabat al-Jamī' al-Kabīr, Șan'ā’ (Yemen). Source: https://www.islamicawareness.org/quran/text/mss/yem1a (access: April 2019)

It is assumed that the use of the Hijāzī script did not fade away but that its gradual standardisation brought about the emergence of the Kufic script

${ }^{71}$ F. Déroche, op. cit., pp. 135-136; A. Gacek, op. cit., p. 124. 
$(k h a t t k \bar{u} f i)^{72}$. However, this process has not been explained due to the lack of sufficient sources ${ }^{73}$. One of the earliest extant inscriptions in the Kufic script is the inscription engraved in a rock near Aț-Ṭā'if in Al-Hijāz which informs about the construction of a dam by Caliph Mu'āwiya in $58 / 677-8$ in that place. The shapes of the letters are distinct and legible, the letters $b \bar{a}^{\prime}, t \bar{a}, t \underline{\bar{a}}$, $h \bar{a}, f \bar{a}$ ', nūn, $y \bar{a}$ ' featuring diacritical marks, the words separated from each other, the inscription itself harmoniously outlined ${ }^{74}$.

The Kufic script was used in the Umayyad period (41-132/661-750) and in the first centuries of Abbasid rule (132-656/750-1258) especially for writing the Qur'anic text - here its popularity lasted until the 4 th/1oth century. It was used to write inscriptions on coins, as well as monumental architectonic inscriptions which served clear ornamental purposes. In architecture, the Kufic script passed out of widespread use during the 5 th-6th/11th-12th century. The name of the script refers to the Iraqi garrison city of Kufa, which was established in $17 / 638$, and which constituted in the early period of Islam one of the major intellectual centres of the caliphate.

The term "Kufic script"75 involves a number of different varieties of a monumental script, which feature an angular instead of a round line of letters. Despite the doubtless variety between the particular Kufic scripts, the solutions which recurred predominantly included a bulky form of letters, horizontal elongation in the bases of letters, relatively considerable spacing between the alif and a neighbouring letter. Moreover, the stems of the letters were almost perpendicular to the base; the letters mim and $w \bar{a} w$ did not go below the line, and alif was hooked at the bottom of the stem from the right-hand side. In the early Kufic script diacritical marks for distinguishing homographs were not regularly used. Featured especially in the copies of the Qur'an, they usually took the shape of fine strokes placed above and below letters. The spacing between words was small, similar to the spacing between

${ }^{72}$ This script is laconically mentioned by Ibn an-Nadīm, who links it with a group of copyists of the Qur'an who were active during Caliph Mu'tașim's tenure (218-227/833-842), B. Dodge, op. cit., Vol. 1, p. 12.

${ }^{73}$ P. M. Sijpesteijn, op. cit., p. 518.

${ }^{74}$ Sh. Blair, op. cit., pp. 85-86.

${ }^{75}$ F. Déroche suggested the replacement of the term 'Kufic', which was introduced to the Western scholarly discourse in the 18th century, with the term "early Abbasid" due to the fact that not all manuscripts and inscriptions made in this script are associated with Kufa. However, this term may be confusing, for the development of the "early Abbasid script" preceded the period of Abbasid rule, A. Gacek, op. cit., p. 97; Sh. Blair, Kufic, pp. 597-598. 
letters in a word. There was a tendency to align the writing to the left - by extending the connections between the letters or the bases of letters ${ }^{76}$ [Fig. 4 and 5].

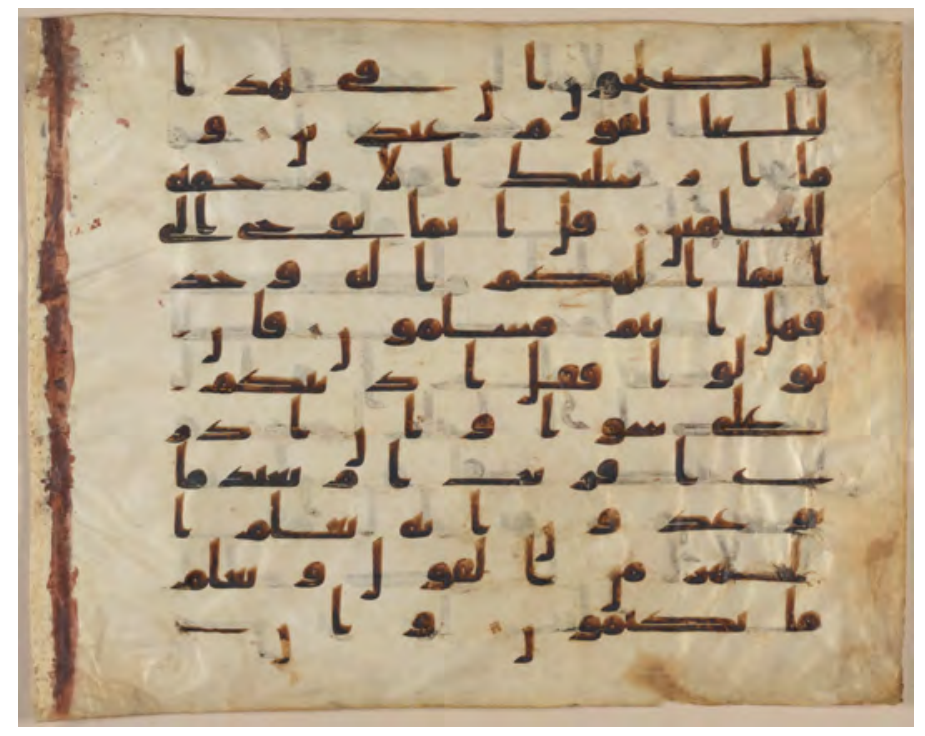

Figure 4: A folio from a Qur'ānic Manuscript (late 8th - early 9th century) in the Kufic script with no diacritical marks, ink on parchment, attributed to Syria or North Africa. Current location: The Metropolitan Museum of Art. Source: https://www.metmuseum.org/toah/works-of-art/2004.87/ (access: April 2019)

Sporadic use of diacritical marks in early copies of the Qur'an may indicate that the writing served merely as a memory aid for the content which functioned in oral transmission. In spite of the fact that the cultural emphasis on the memorisation of the Qur'an and the aural form of divulgation was present throughout the entire history of the Arab-Muslim world, in the course of time a complete $i$ ' $j \bar{a} m$ was introduced (along with the extending boundaries of the Muslim empire, the Muslim umma came to involve an ever growing number of non-Arab people, for whom the "shorthand record" of the text of the revelation was illegible). The systematisation of the writing of the diacritical marks ( $i^{i} j \bar{a} m$ ) occurred at the beginning of the 2 nd/8th century ${ }^{77}$. The Arab tradition associates this solution with Al-Hajajāj Ibn Yūsuf

${ }_{76}$ A. Gacek, op. cit., pp. 97-98; Sh. Blair, Kufic..., pp. 598-599.

77 On the vowel marks associated with $f \bar{a}$ ' and $q \bar{a} f$ until the early 2 nd/8th c. see e.g. F. Déroche, 
(d. 95/714), who was the governor of Iraq since 75/694. Being known for exceptional linguistic purism, he allegedly commissioned a writer, Nașr Ibn 'Áșim al-Layțî, to introduce of diacritical marks as one of the endeavours in the fight against the erroneous reading of the Qur'anic text. Another version of this account claims that this task was entrusted to Naşr and a well-known philologist Yahyā Ibn Ya'mar (d. 129/746). Finally, a third version also mentions an Arab ascetic, Al-Hasan al-Bașrī (d. 110/729), who was obliged by the Iraqi governor to introduce the $i^{\prime} j a \bar{m}$, along with Yahyā Ibn Ya' $\mathrm{mar}^{78}$.

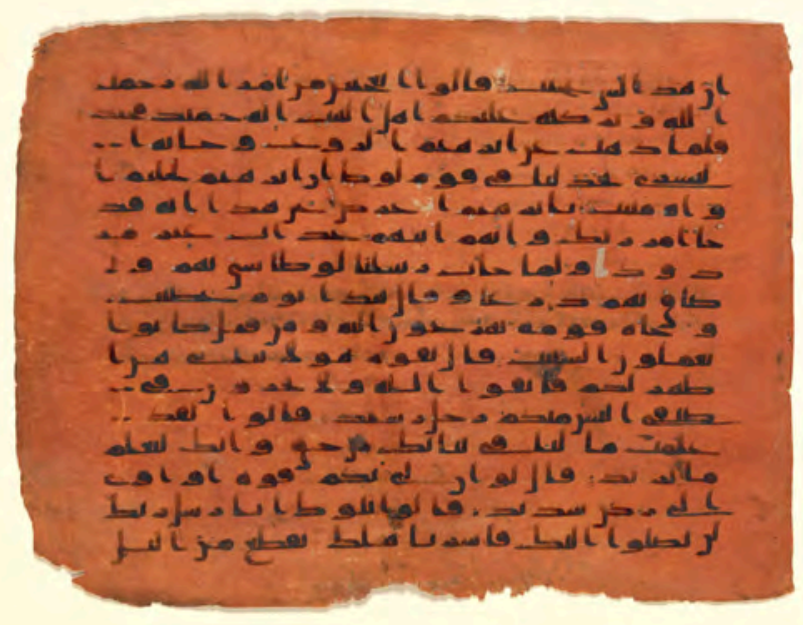

Figure 5: A folio from a Qur'ānic Manuscript (probably 9th century) in the Kufic script with a limited use of diacritical marks, ink on dyed parchment, attributed to central Islamic lands. Current location: The Metropolitan Museum of Art. Source: https://www.metmuseum.org/toah/works-ofart/40.164.1a/ (access: April 2019)

contrib. A. Berthier et al., Islamic Codicology: an Introduction to the Study of Manuscripts in Arabic Script, pp. 220-221.

${ }^{78}$ Z. I. Oseini, An Examination of Al-Hajjäj b. Yūsufal-Thaqafì's Major Policies, p. 319; N. Abott, op. cit., pp. 38-39. Along with the establishment of the principles of the recitation of the Qur'an additional marks (abbreviations) began to be introduced to the manuscripts, which indicated e.g. the places in the text where pausing was admissible, not permitted or mandatory, when one could take a breath and when one had to read continuously, when one was supposed to observe the principles of the assimilation of sounds etc. 
The presence of diacritical marks at the grapheme $d$ in the transitional Nabataean inscriptions from the $3 \mathrm{rd}^{-} 5^{\text {th }}$ century ${ }^{79}$, in the earliest Arab papyri and in the early copies of the Qur'an in the Hijāzī script indicates that their use in the Arabic script may have Nabatean roots ${ }^{80}$.

It is worthwhile, in passing, to particularise that also in the subsequent period the i $i j \bar{a} m$ was not consistently applied, particularly in official correspondence and in highly specialised texts of the state administration (e.g. in receipts, legal contracts). Some classical authors claimed that the use of the $i j \bar{a} m$ in official correspondence was an outrage against the reader ${ }^{81}$. Selective use of diacritical marks may also be discerned in informal records and notes taken for private purposes. However, in the remaining cases, diacritical marks were applied and they were treated as an integral part of the text, and the lack of these marks indicated that the copyist/scribe lacked appropriate education $^{82}$.

\section{The development of the cursive script}

An important decision which supported the further development of the script and its standardisation, especially in the case of the script featured in papyri, was associated with the introduction of the Arabic language to the chancellery of the caliphate. The decision was made by the fifth Umayyad caliph, 'Abd al-Malik (65-86/685-705) as a part of the reforms whose purpose was to nationalise the state (on the lands which as a result of conquests were incorporated into the nascent Arab-Muslim empire initially there functioned the former models of the bureaucratic apparatus: the Byzantine model and the Persian model; the Arabs eventually opted for the Persian model which was codified in the course of time $)^{83}$. Owing to 'Abd al-Malik's decision the Arabic script saw an accelerated development in its practical varieties. The administrative script enabled a relatively quick method of recording ${ }^{84}$. Des-

${ }^{79}$ See. L. Nehmé, op. cit., pp. 55-59.

${ }^{80}$ A. Gacek, Arabic Manuscripts. Vademecum for the reader, p. 144; B. Gruendler, Arabic Alphabet..., p. 151.

${ }^{81}$ A. Gacek, Arabic Manuscripts..., p. 145; P. M. Sijpesteijn, op. cit., pp. 515-516.

${ }^{82}$ A. Gacek, Arabic Manuscripts..., p. 145, 216; Sh. Blair, Islamic..., p. 81.

${ }^{83}$ The languages which were theretofore used in the administration were not abolished right away; they were used for some time after Arabic was adopted.

${ }^{84}$ Linguistically this was a very important decision, for thus Classical Arabic, which had mainly been the language of the Qur'an and pre-Islamic poetry, began to enrich its lex- 
pite the exiguous number of textual artefacts of administrative nature, the subsequent sources preserved the memory about their rapidly growing number $^{85}$. One of the earliest extant official documents originated not from the Damascus chancellery but from the local Umayyad chancellery. It is a group of Arabic- or Arabic- and Greek-language papyri which date back to the age of Qurra Ibn Šarīk, a governor of Egypt $(90-96 / 709-714)^{86}$.

According to the modern typology developed in the Western context, the style of the chancellery script is set against the style featured in early records of the Qur'anic text and in the inscriptions, referring to the former as the cursive or the naskhi script (naskh - literally 'copying') ${ }^{87}$. The semantic scope of the term naskhi covered all, and subsequent, stylised scripts featuring rounded letter forms and it began to be used interchangeably with the term naskh which refers to one of the most practical and popular varieties of the cursive script (functioning in the eastern part of the Islamic word beginning from the turn of the 5 th/11th century), which caused some terminological confusion ${ }^{88}$. However, as far as the term "cursive" is concerned, considering the fact that one of the main exponents thereof has to do with the linking of letters, the Arabic script itself is inherently a cursive script. Eva Mira Grob, who performed a paleographical analysis of early private and chancellery records in papyri suggested a particularisation of the peculiar features of the "cursive" in the Arabic context. Apart from rounded letter forms (the script is also referred to as a round script), distinct inter-word connections (keeping a steady flow of writing), slight spacing between groups of letters (cohesion of writing), it adds a wide angle of writing (i.e. the angle constituted by the vertical line determined by the stems of letters and the line of the word which assumes a descending direction $)^{89}$.

The cursive script developed slowly and the first pieces of writing on papyrus cannot be said to represent cursive in the aforementioned, complete

icon with new vocabulary, to confer new meanings to existing vocabulary, and partly also to introduce syntactic changes that transformed it into une langue de civilisation.

${ }^{85}$ Sh. M. Toorawa, Ibn Abì Țāhir Țayfūr and Arabic Writerly Culture. A ninth-century bookman in Baghdad, p. 8.

${ }^{86}$ Discovered in 1902 in Upper Egypt, in the Kūm Ishqāw village, which was known in ancient times as Aphrodito. Fr a more comprehensive treatment see N. Abott, The Kurrah Papyrifrom Aphrodito in the Oriental Institute.

${ }^{87}$ E. M. Grob, Documentary Arabic Private and Business Letters on Papyrus. Form and Function, Content and Context, s. 161.

${ }^{88}$ N. Abott, The Kurrah Papyri..., p. 34; A. Gacek, Arabic Manuscripts..., p. 162.

${ }^{89}$ E. M. Grob, op. cit., pp. 161-168. 
sense of this word. Due to the lack of a sufficient amount of extant documents, it is difficult to trace the development of the particular variants of this script. It occurred especially in the $2 \mathrm{nd} / 8$ th century. It is assumed that the impulse which prompted this development must have originated from the central areas of the caliphate, and owing to the well-functioning administrative infrastructure (including the post system infrastructure) the solutions which were adopted there were transmitted further afield ${ }^{90}$. It was only when the script became a staple in the day-to-day life, in the private and official correspondence, in legal and administrative documents, trade contracts etc. that it expanded its range and came to be used for copying manuscripts. Its value was appreciated as a vehicle for the dissemination and preservation of knowledge. It was more legible and copying texts took less time, while the same writing surface could contain more text.

The improvement of the script and the writing materials was accompanied by the development of orthography. Apart from the previously mentioned i'jām, an important step forward in this regard was associated with the introduction of short vowels $a, i, u$ in the form of single or, in the case of nunation, double dots. The system of vocalisation/vowel marks (tashkill) was developed, as in the case of $i$ ' $j a \bar{m}$, above all for the purposes of the Qur'an and its transmission in written form ${ }^{91}$. Even though some copies of the Qur'an in the Kufic script, starting from the $2 \mathrm{nd} / 8$ th century manifest the indication of vowels in the form of dots written in red ink (but never in a complete form), it is difficult to say precisely when this system was introduced. Vocalisation introduced with a different colour was an activity independent from the copying of the text and it could have been introduced in a subsequent period (by a copyist/scribe) who was specialised in vocalisation of the text) ${ }^{92}$. In the majority of cases the Arabic tradition ascribes the introduction of this system to Abū Aswad ad-Du'alī (d. ca 67/686), which is associated with the beginnings of Arabic linguistics, although the similarity to the system of indicating vowels in the Syriac scripts demonstrates that it is rather a continuation of this tradition ${ }^{93}$.

${ }^{90}$ P. M. Sijpesteijn, op. cit., p. 518 .

${ }^{91}$ F. Déroche, contrib. A. Berthier et al, op. cit., p. 222.

${ }^{92}$ Ibidem; N. Abott, The Kurrah Papyri..., p. 39; A. Gacek, Arabic Manuscripts..., pp. 288-289. In the early copies of the Qur'an one did not take into account the final/medial forms of the alif. It was written later in red ink in the superscript. This solution was sometimes adopted also in subsequent Qur'anic manuscripts until the 9th/15th century, A. Gacek, Arabic Manuscripts..., p. 219.

${ }^{93}$ F. Déroche, contrib. A. Berthier et al, op. cit., p. 222; A. Gacek, Arabic Manuscripts..., p. 288. 
In the place of dots, in the course of time vocalisation marks were introduced in the form of small alif, $y \bar{a}$ ' and $w \bar{a} w$ letters written above and below consonantal signs. This change is ascribed to a grammarian and lexicographer, Khalīl Ibn Ahmad al-Farāhidī (d. ca 175/791). In reality the extant manuscripts with new vocalisation marks date back to a slightly subsequent period - from the $3 \mathrm{rd} / 9$ th century. Short vowels were indicated in non-black colour ink, usually red, or sometimes golden and silver. Such a state of affairs lasted at least until the 6th/12th century, and in some regions of the Islamic world even longer ${ }^{94}$. Khalīl Ibn Ahmad al-Farāhidī allegedly also introduced the hamza. Its graphical form, as well as the spelling regulations associated with it depending on the position in a word evolved in time. The change involved both the colours that were used as well as the graphical form of the sign ${ }^{95}$.

Apart from alphabetical signs which represented sounds other symbols were also introduced in order to ensure correct pronunciation: the shadda, sukūn, wașla or madda. Also these enhancements are linked by Arab tradition with the figure of Al-Farāhidī. These signs, which were used similarly as in the case of short vowels above all in the text of the Qur'an, underwent slow changes. For example initially the shadda was indicated in the form of a yellow, blue or orange dot, then in the form of a small semicircle ( $v$ or $n$ ) with the use of red ink ${ }^{96}$, finally the letter $\operatorname{sh}$ in (in the initial form, without diacritical marks) ${ }^{97}$.

In the course of time, the manuscripts also witnessed the use of graphical signs whose purpose was to separate semantic units in the text, although they were not consistently applied and they depended on the type of writing. Punctuation understood as the graphical equivalent of the intonation, rhythm and rate of speech, of lexical and sentence stress did not exist until the end of the age of manuscripts.

The earliest graphical marks which separated the particular sentences or portions of a text were slanting lines $(/ / /)$ in one or two rows, as well as round or rhomboid points arranged, for example, in the form of a triangle $(\therefore)$ [Fig. 3]. They were used in papyri and in the text of the Qur'an - here they

${ }^{94}$ F. Déroche, contrib. A. Berthier et al, op. cit., p. 223; N. Abott, The Kurrah Papyri..., p. 39.

${ }^{95}$ N. Abott, The Kurrah Papyri..., p. 40; A. Gacek, Arabic Manuscripts..., p. 289.

${ }^{96}$ It is difficult to ascertain in an unambiguous way whether at this stage this was already an adaptation of the letter shin, N. Abott, The Kurrah Papyri..., p. 40.

${ }^{97}$ Ibidem, pp. 40-41; A. Gacek, Arabic Manuscripts..., p. 289; F. Déroche, contrib. A. Berthier et al, op. cit., p. 223 . 
separated two verses or groups thereof from each other. The manuscripts of the Qur'an also features stylised flowers, rosettes as well as the letters $h \bar{a}^{\text {' }}$ (ه) or $y \bar{a}^{\prime}$ (ي). Due to the numerical value 5 which corresponds to the letter $h \bar{a}$, and the value 10 which corresponds to the letter $y \bar{a}$, these elements appeared after a group of five and ten verses, respectively. Other texts usually employed inverted commas ( (), circles with a dot in the middle $(\odot)$, dots, the letter $h \bar{a}^{\prime}(0)$ in various forms (it was treated as an abbreviation of the word intih $\bar{a}$ - the end), as well as rosettes. A different colour was used to emphasise the titles of chapters and substantial words, usually those which initiated a new thought. One sometimes drew a horizontal line above the latter ${ }^{98}$ [Fig. 6 and 7 ].

The lack of a system of punctuation was mainly a result of the fact that the basic model of the transmission of content was listening, and the tradition of memorisation constituted one of the basic models of education. Therefore one ran the risk that the manner of the spelling out (interpreting) of the text or a fragment thereof would be ambiguous. The one who pronounced the text transmitted its entire illocutionary force. Moreover, the sense and the meaning itself of an utterance was usually determined by referring to an authority, not by the interpretation of the specific terms, for which the punctuation could constitute one crucial hint ${ }^{99}$.

${ }_{98}^{8}$ A. Gacek, Arabic Manuscripts..., pp. 269-270; F. Déroche, contrib. A. Berthier et al, op. cit., pp. $240-241$.

${ }^{99}$ Until the turn of the $3 \mathrm{rd} / 9$ th century as a rule one did not confer a final form to works and they did not function as manuscript books sensu stricto, and merely as informal notes to aid the memory, G. Schoeler The Genesis of Literature... , p. 46 passim. 


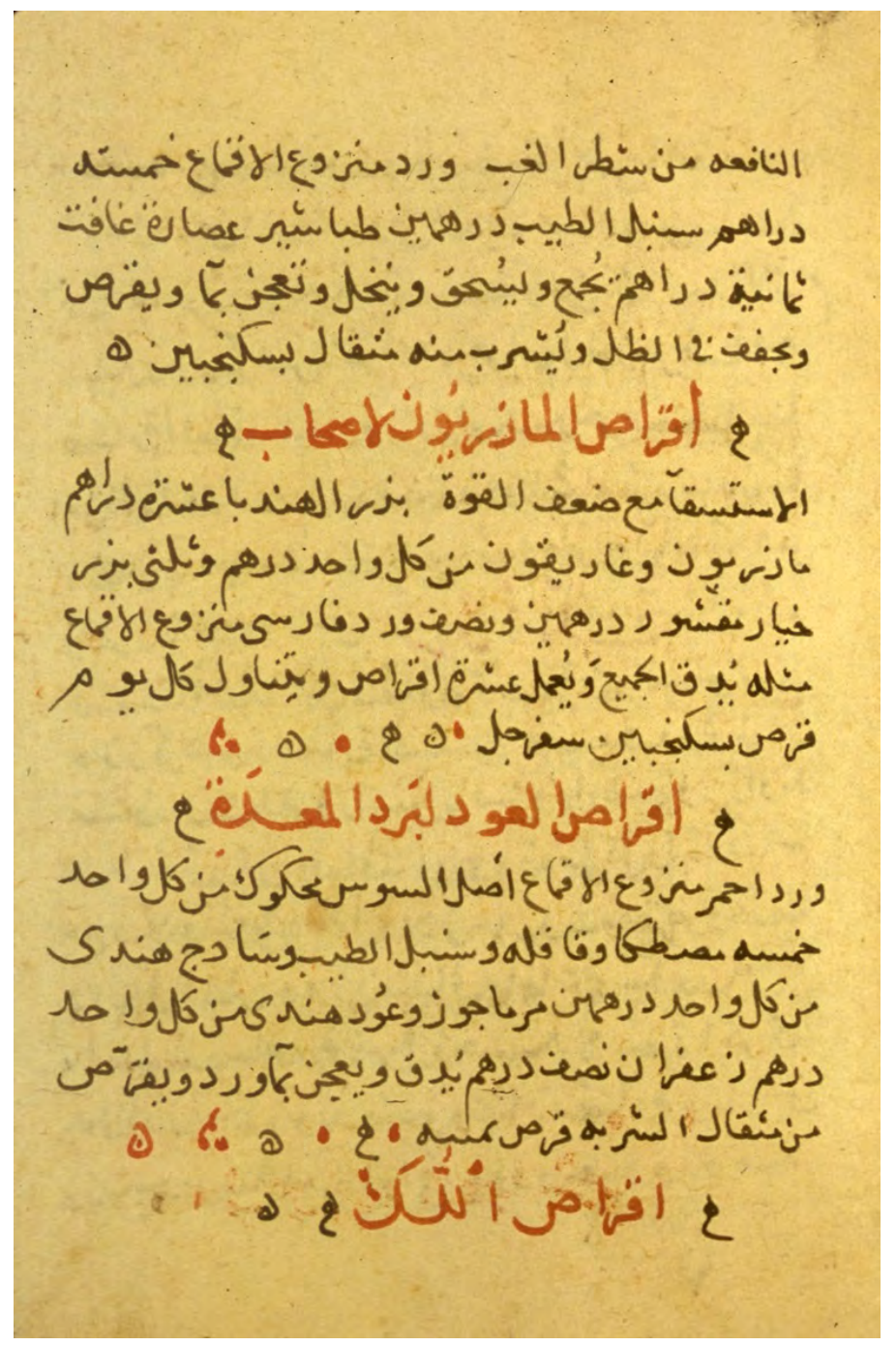

Figure 6: A folio of a formulary of compound remedies - aqrāb $\bar{a}$ dhin (15th century), in the medium-small naskh script (one of the Six Pens scripts), ink on paper with headings in red and marks which indicated the end of five-verse chapters. Current location: National Library of Medicine, Bethesda, Maryland. Source: https:// www.nlm.nih.gov/hmd/arabic/pharmaceutics32.html (access: April 2019) 


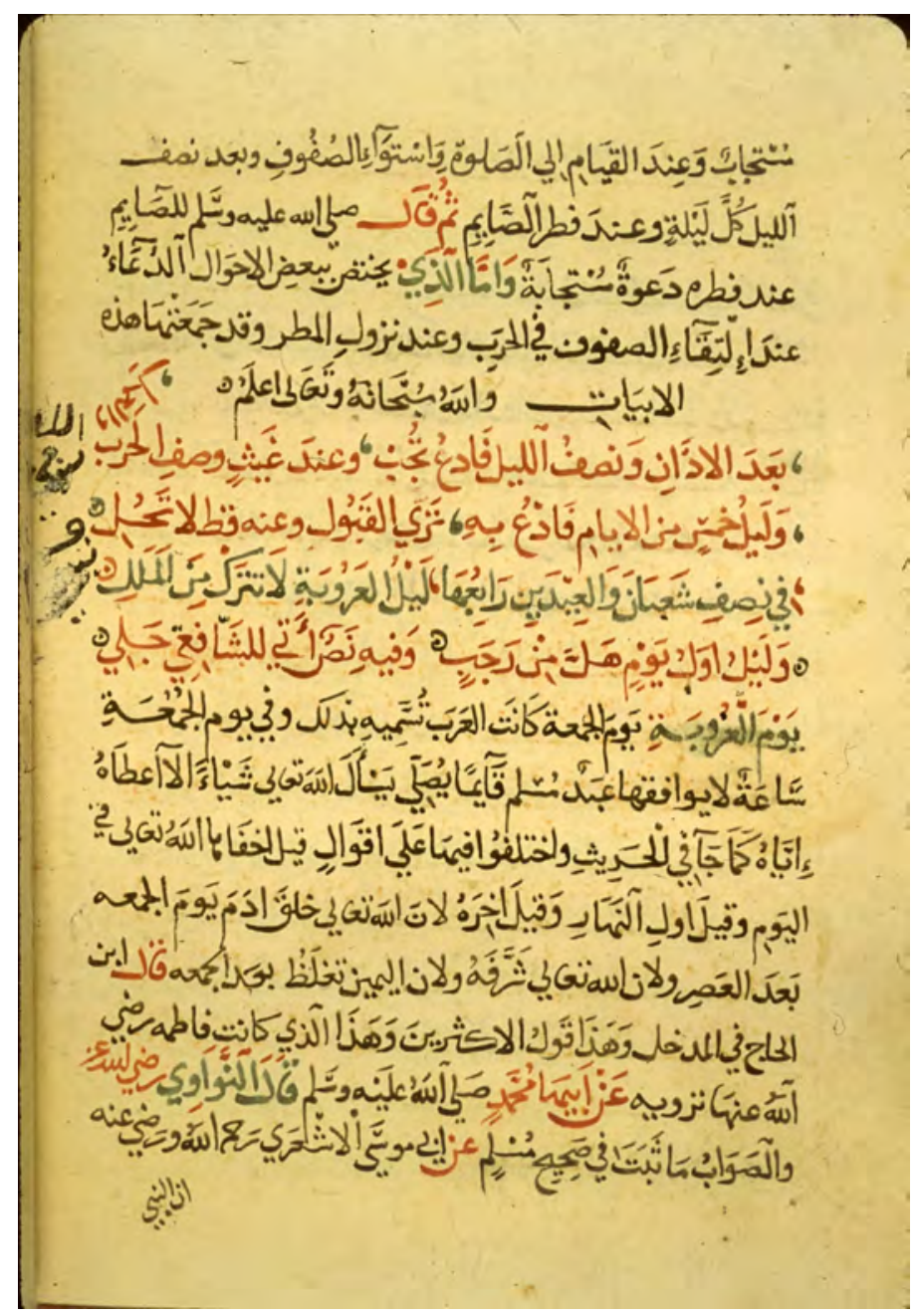

Figure 7: A folio from an Adab treatise (probably 15th-16th century), in the medium-small naskh script (one of the Six Pens scripts), ink on paper, red and/or green ink was used to indicate verses of poetry and the beginning of a commentary; the beginning and the end of verses was indicated by an inverted comma/or a circle with a dot at the centre. Current location: National Library of Medicine, Bethesda, Maryland. Source: https://www.nlm.nih.gov/hmd/arabic/adab_literature2.html (access: April 2019). 


\section{The development of Arabic calligraphy}

Over time, the informative function of the cursive script was extended by an aesthetic element. In the official correspondence, and in the private correspondence as well, the type of the script (and the writing materials) that were used depended on the status of the recipient, the sender and the content of the letter. Similarly, the variety of the documentation (various kinds of contracts, reports, consultations etc.) determined the choice of script. In due course, increasing attention was attached to the beauty of the Arabic script, of the particular letters and the sheer infinitude of the possibilities of creating new forms of this script. When the aesthetic function dominated the information function, the script became an art. Calligraphy came to occupy an exceptionally privileged position among other branches of art ${ }^{100}$ (after the emergence and the consolidation of calligraphy, the ornamental function of the script was also used in architecture and in handicraft). The history of the development of various styles of calligraphy has not been completely explored, the bulk of the contributions in this field being ascribed to the central Abbasid administration. It is known that from the middle of the $3 \mathrm{rd} /$ second half of the 9 th $\mathrm{c}$. the improved cursive script existed in many varieties (contemporarily a range of suggested terms has been elaborated to refer to stylised cursive varieties/styles of writing e.g. broken cursive, or the New Abbasid Style, or New Style - as an abbreviation) ${ }^{101}$. This diversity, which arose in the central administration, overlapped with the diversity which occurred on a macro scale, as a consequence of a particular political situation: the autonomisation of particular provinces and their break away from the centre of the caliphate was conducive to "artistic diversification" and the multiplication of a growing number of new regional varieties ${ }^{102}$ (thus, for example, the western part of the empire saw the development of Maghrebi script - khatt maghribi - and its varieties which in the course of time came to be used in the entire North Africa, Arab Spain and Sub-Saharan Africa).

In the 4 th/1oth century, most likely for the purpose of the standardisation of broken cursive, the khatt mansū b system was developed, (aqlām mansūba, kitāba mansū $b a)^{103}$, i.e. a system which determined the proportions of the

${ }^{100}$ For a more comprehensive treatment see B. Prochwicz-Studnicka, The Origins of High Significance of Writing in Arab-Muslim Culture, pp. 217-233.

${ }^{101}$ Sh. Blair, Islamic..., p. 144; F. Déroche, contrib. A. Berthier et al., op. cit., p. 217.

${ }^{102}$ Sh. Blair, Islamic..., p. 143; P. M. Sijpesteijn, op. cit., p. 519.

${ }^{103}$ The translation of hatt mansūb as proportioned writing was suggested by Nabia Abott on 
particular letters for the particular cursive scripts. The name which is invariably associated with this endeavour is that of the vizier on the Abbasid court, Ibn Muqla (d. 328/940), although there are no extant instances of the script which could be ascribed to him in an unambiguous manner, and the authenticity of his dissertation on the subject of calligraphy, Risāla fì 'ilm al-khatt wa-l-qalam, is sometimes called into question ${ }^{104}$. According to Janusz Danecki ${ }^{105}$ :

Ibn Mukla's system was clearly geometrical in nature: the proportions resulted from complex relations between the particular letters. The basis of this system was associated with the following: a circle inscribed into a square and a pentagon and two rhombi inscribed into a circle, whose diameter was constituted by the Arab letter alif (which has the form of a vertical stroke/line - |). The proportions were measured by means of a dot which had the form of a small rhombus. The dot was made when one applied the reed to the paper with some force.

This system was corrected and perfected by Ibn al-Bawwāb (d. 413/1002), a man who was associated with Baghdad, initially illuminator of manuscripts, who was recognised by subsequent historiographers as an unsurpassed master of calligraphy ${ }^{106}$. Thus there emerged six classical varieties of writing (alaqläm as-sitta) ${ }^{107}$, which became dominant in the Muslim East over time [Fig. 7 and 8]. The third icon of classical Arabic calligraphy is a man who was active two centuries later - Yāqūt al-Musta'ṣimī (d. 698/1298), a slave who was raised and educated by the last Abbasid caliph Al-Musta'șim (640-656/1242-1258). Yāqūt established a school of calligraphers in Baghdad, in which he continued the work of his predecessors, subjecting the so-called six styles to further aestheticisation and refinement.

the basis of the idea of the correspondence of the constituent elements of a letter, basic for Ibn Muqla's system. These elements were related (nusiba) to the size of the alif as the fundamental measure, N. Abott, The Rise..., p. 35.

${ }^{104}$ A. Gacek, Arabic Manuscripts..., p. 44.

${ }^{105}$ J. Danecki, Kultura i sztuka islamu, p. 105.

${ }^{106}$ Sh. Blair, Islamic..., p. 161.

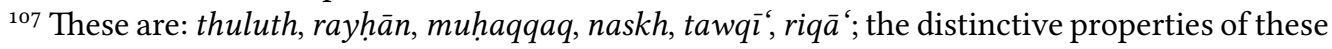
types of writing, their applications and the functioning in the post-classical world is discussed, among others by Sheila Blair and Adam Gacek. 


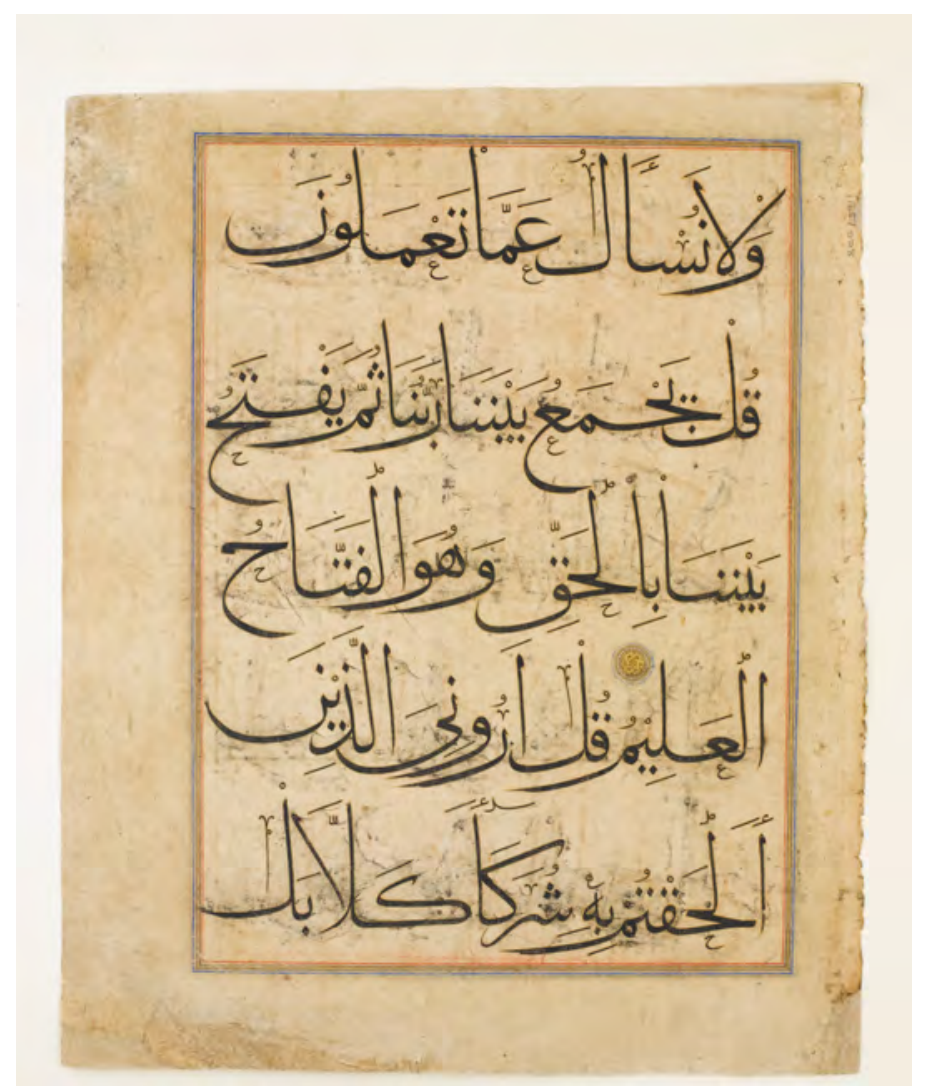

Figure 8: A folio from a Qur'ānic Manuscript (14th century) in the muhaqqaq script (one of the Six Pens scripts), rosettes mark the end of each verse, ink, gold, and opaque watercolour on paper, possibly made in Iraq, Baghdad. Current location: The Metropolitan Museum of Art. Source: https://www.metmuseum.org/toah/works-of-art/2008.31/ (access: April 2019).

The reasons for the standardisation of the script must have been complex. Without doubt, the most important had to do with the introduction of paper as a writing material. It is assumed that the acquisition of paper product techniques is owed to an incident which occurred as a result of a battle on the Talas River (Arabic: Tarāz) in 133/751 in the eastern borderlands of the Empire, a battle in which the Muslim army defeated the Chinese army and indirectly contributed to the fact that the Chinese gave up their plans to occupy Central Asia. Among those who were taken into captivity were supposedly some Chinese paper makers, who (perhaps in return for their life 
or freedom) familiarised the Arabs with the technology of paper production. They are thought to have been taken to Samarkand and in the same year to have established there the first paper-making facility in the Muslim lands. Despite the overt naivete which is inherent within this usually questioned account, one should emphasise that indeed in the $2 \mathrm{nd} / 8$ th century paper was a recognised and valued commodity in the Persian lands ${ }^{108}$.

The adoption of paper as a writing material in the Arab-Muslim world occurred slightly later, although in Baghdad itself the first paper making facilities are supposed to have been established in the same century, and a century later in Damascus, Hama and Tripolis. Paper reached Egypt from Syria in the same century, but the domestic production of paper in Cairo began

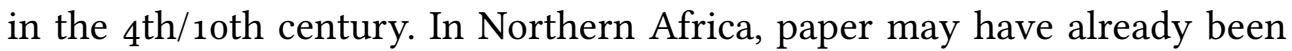
known in the $3 \mathrm{rd} / 9$ th century, but its use began around the 5 th/11th century (parchment retained its popularity as a writing material mainly for economic reasons - Ifrīqyā was a region where the rearing of sheep and the leather industry, including the parchment industry flourished, and retained a strong position on the production market for a long time $)^{109}$.

In the East parchment and papyrus lost their viability as writing materials relatively quickly ${ }^{110}$, for hemp, linen, ramie (Boehmeria nivea) - i.e. plants which were common in the Near East - were suitable for the production of paper. In contrast to parchment, which was accessible in the Nile Valley, as well as skins, whose production was limited due to economic reasons, paper turned out to be a generally accessible and cheap material. Moreover, its structure absorbed pigments and ink better ${ }^{111}$. Finally, it was more suitable for the creation of codices than papyrus and parchment (from which codices were made but they assumed also the form of rotuli).

${ }^{108}$ See J. Bloom, Paper before Print. The History and Impact of Paper in the Islamic World, pp. 42-45; H. Loveday, Islamic Paper. A Study of the Ancient Craft, pp. 18-19.

${ }^{109}$ For a more comprehensive treatment of the subject of the establishment of paper-making facilities in the particular cities, the type of the paper which was produced and the early extant artefacts of writing on paper see. J. Bloom, Paper before Print..., pp. 46-89.

${ }^{110}$ The production of papyrus as a writing material was monopolised by Egypt, where around the 5 th/11th century production ceased. Parchment was already common in the east of the Empire in the $4^{\text {th/1 }}$ oth century (in the West it was widespread for a much longer period of time), but the increase in the demand associated with writing materials was so great that the production of parchment could not keep up with the requirements of the market at that time. It was quickly taken over by the papermakers. For a more comprehensive treatment see A. Gacek, Arabic Manuscripts..., pp. 193-196; H. Loveday, op. cit., pp. 10-15; F. Déroche, contrib. A. Berthier et al, op. cit., pp. 26, 34 .

${ }^{111}$ H. Loveday, op. cit., p. 23; J. Bloom, Paper before print... op. cit., p. 45. 
Along with the spread of paper, carbon-black ink was introduced on a wider scale. It did not spoil the paper and was relatively durable. It was made from soot acquired from the combustion of certain plant species (pigment), which was then mixed with water (solvent) and honey or gum arabic (binding agent). Carbon-black ink was used to write on papyri, yet it was not suitable for writing on parchment, for it could be easily washed away; it tended to come off the surface, whereas the iron-gall ink, which was used for writing on parchment, could not be applied in the case of paper, because it leaked through the material and in the course of time it spoilt it (a phenomenon known as ink corrosion) ${ }^{112}$.

The introduction of paper as a writing material coincided with the gradual replacement of the Kufic script in the copying of the Qur'an by broken cursive. The earliest extant instance of the Qur'an written in broken cursive from $361 / 972$ is at the same time the earliest instance of a Qur'anic text written on paper ${ }^{113}$. The abandonment of the Kufic script in the copying of the Quran did not signify the decline of this script at all. Although the round script had begun to replace the Kufic script in architecture since the late $5^{\text {th}} / 11$ th century, the latter was reinstated locally in a number of varieties in the post-classical period, mainly as an ornamental element of architecture and foundation inscriptions. Sometimes it was also used in the title folium of the Qur'an ${ }^{114}$.

Along with the Mongol raid and the fall of the Abbasid caliphate the cultural dimension of Islam began to undergo growing regional and dynastic diversification ${ }^{115}$. The Six Pens remained in use in the form of chancellery scripts, for the copying of manuscripts and as an ornamental element in art, although some of them lost their popularity in various regions and underwent transformations; new varieties also arose. Due to the fact that

${ }^{112}$ The colour of the iron-gall ink (or, more broadly: metal-tannic ink) was acquired by a combination of iron compounds with tannin derived from gall, in most cases. This ink was absorbed by the parchment like a pigment. For a discussion of the additional components of both basic types of inks and the methods of obtaining other colours see J. Bloom, Paper before Print..., p. 107; A. Gacek, Arabic Manuscripts..., pp. 132-135; Sh. Blair, Islamic..., pp. 61-63; F. Déroche, contrib. A. Berthier et al, op. cit., pp. 113-153.

${ }^{113}$ J. Bloom, Paper before Print..., p. 106. The first extant instance of the Qur'an in the round script dates back to 292/905; it was developed in parchment and it represents an experimental script in which the scribe attempted to confer monumental features to the round script, Sh. Blair, Islamic..., pp. 147-148; eadem, Kufic..., p. 601.

${ }^{114}$ Sh. Blair, Kufic..., s. 601.

115 The varieties of calligraphy which dominated at that time, presented according to regions and dynasties in: Sh. Blair, Islamic..., Part IV - V, pp. 241-585. 
the Islamic world slowly came to adopt new technologies, the end of the manuscript era occurred as late as at the turn of the 14th/2oth century, i.e. in the period when the Near East had discovered and started using print ${ }^{116}$.

$$
* * *
$$

In the broadest sense, writing is a codified system whose purpose is to transmit ideas. It registers the spoken word, communicates and preserves it. "Written language has become the vehicle of civilization, and so of learning and education," according to David Diringer, who added that "writing is thus one of the main aspects of culture which clearly distinguish mankind from the animal world." ${ }^{117}$ Writing created a discourse which is completely different from oral narration. It began to influence its maker by opening him to new methods of thinking about and interpreting the world. Thus it became a fundamental factor that transformed culture. The implications of literacy did not fail to affect Arab culture. The discourse of writing managed to transform the oral order into a new and complex civilisational structure ${ }^{118}$ (although it is true that vast residua of orality survived for a long time in the Arab-Muslim culture). Hence it seems important to familiarise oneself with the development and the formation of the script itself in the history of this culture.

The article is an overview devoted to the issue of the Arabic script: its genesis, the directions and the causes of its development on the basis of the current state of knowledge in this field. One may discern research into the history of the Arabic script still poses many conjectures and suppositions, conditioned above all by the scant source material. Despite the lack of certainties, the role of the contacts with the Nabataeans and the subsequent role of the central administration of the Abbasid state seems to be undeniable in the process of the development and the normalisation of the particular styles of writing. The hypothesis about the role of Christian communities in the development of Arabic script received substantial argumentation in scholarly discourse, similarly to the hypothesis about the bidirectional development of the script almost from its inception.

\footnotetext{
${ }^{116}$ A. Gacek, Arabic Manuscripts..., pp. 152-153; P. M. Sijpesteijn, op. cit., p. 519.

${ }^{117}$ D. Diringer, op. cit., p. 17.

${ }^{118}$ This problem (in the macro scale) is explored inter alia by Jack Goody's book, op. cit.
} 


\section{Bibliography}

1. Авотт N., The Kurrah Papyri from Aphrodito in the Oriental Institute, The University of Chicago Press, Chicago 1938.

2. Авотт N., The Rise of the North Arabic Script and its Kur'ānic Development, with a Full Description of the Kur'ān Manuscripts in the Oriental Institute, Chicago University Press, Chicago 1939.

3. Bellamy J. A., A New Reading of the Namärah Inscription, "Journal of the American Oriental Society" 105 (1/1985), pp. 31-51.

4. Bellamy J. A., Two Pre-Islamic Arabic Inscriptions Revised: Fabal Ramm and Umm al-fimāl, "Journal of the American Oriental Society" 108 (3/1988), pp. 370-372.

5. Bellamy J. A., The Arabic Alphabet, [in:] W. M. Senner (ed.), The Origins of Writing, University of Nebraska Press, Lincoln 1991, pp. 91-102.

6. Blair Sh. S. Islamic Calligraphy, Edinburgh University Press, Edinburgh 2006.

7. Blair Sh., Kufic, [in:] K. Versteegh (general ed.), K. Versteegh (general ed.), Encyclopedia of Arabic Language and Linguistics, Brill, Leiden Boston 2008, Vol. 2, s. 597-604.

8. Bloom J. M., Moving Words, [in:] A. B. Sajoo (ed.), A Companion to Muslim Cultures, I. B. Tauris Publishers, London - New York 2012, pp. $137-164$.

9. Bloom J., Paper before Print. The History and Impact of Paper in the Islamic World, Yale University Press, London 2001.

10. von Bothmer H. C. G., Ohlig K. H., Puin G. R., Neue Wege der Koranforschung, "Magazin Forschung" 1/1999, pp. 33-46.

11. BRyce T., The Routledge Handbook of the Peoples and Places of Ancient Western Asia. The Near East from the Early Bronze Age to the Fall of the Persian Empire, Routledge, London - New York 2009.

12. DANECKi J., Gramatyka opisowa jezzyka arabskiego, Wydawnictwo Akademickie Dialog, Warszawa 2001, Vol. 1.

13. Danecki J., Kultura i sztuka islamu, Dom Wydawniczy Elipsa, Warszawa 2003.

14. Daniels P. T., The Arabic Writing System, [in:] The Oxford Handbook of Arabic Linguistics, J. Owens (ed.), Oxford University Press, Oxford New York 2013, pp. 412-432.

15. Déroche F., Qur'ans of the Umayyads. A First Overview, Brill, Leiden - Boston 2014. 
16. Déroche F., contrib. Berthier A., et al, Islamic Codicology: an Introduction to the Study of Manuscripts in Arabic Script, Al-Furqān Islamic Heritage Foundation, London 2005/1426 AH.

17. Diringer D., Alphabet a Key to the History of Mankind, Hutchinson's Scientific and Technical Publications, London - New York - Toronto 1948.

18. Dodge B. (ed. and trans.), The Fihrist of al-Nadim. A Tenth-Century Survey of Muslim Culture, Columbia University Press, New York - London 1970, Vol. 1.

19. GaceK A., Arabic Manuscripts. A Vademecum for Readers, Brill, Leiden - Boston 2009.

20. Gelb I. J., A Study of Writing, The University of Chicago Press, Chicago - London 1963.

21. Ghabbān 'A. I. I., Hoyland R., (trans. and concluding remarks), The Inscription of Zuhayr, the Oldest Islamic Inscription (24 AH/AD 644-645), the Rise of the Arabic Script and the Nature of the Early Islamic State, "Arabian Archeology and Epigraphy" 19 (2/2008), pp. 210-237.

22. Al-Ghul O., Early Inscription from Petra Carrying Diacritic Marks, "Syria" 81 (2004), pp. 105-118.

23. Goody J., The Logic of Writing and the Organization of Society, Cambridge University Press 1986.

24. Graf G., Geschichte des christlischen arabischen Literatur, Biblioteca Apostolica Vaticana, Citta del Vaticano 1944, Band 1.

25. Griffith S. H., Christians and Christianity, [in:] J. D. McAuliffe (ed.), Encyclopaedia of the Qur'ān, Brill, Leiden - Boston 2001, Vol. 1, pp. 307-315.

26. Grob E. M., Documentary Arabic Private and Business Letters on Papyrus. Form and Function, Content and Context, De Gruyter, Berlin New York 2010.

27. Grohmann A., Arabische Paläographie, Hermann Böhlaus Nachfolger, Wien 1967-1971, Band 1-2.

28. Gruendler B., The Development of the Arabic Script: From the Nabatean Era to the First Islamic Century according to Dated Texts, Scholar Press, Atlanta, Ga. 1993.

29. Gruendler B., Arabic Alphabet: Origin, [in:] K. Versteegh (general ed.), Encyclopedia of Arabic Language and Linguistics, Brill, Leiden - Boston 2006, Vol. 1, pp. 148-155. 
30. Healey J. F., The Early Alphabet, University of California Press, Berkeley 1990.

31. Imbert F., L'Islam des pierres : l'expression de la foi dans les graffiti arabes des premiers siècles, "Revue des mondes musulmans et de la Méditerranée" 129 (2011), pp. 57-78.

32. Lecker M., The "Constitution of Medina”. Muhammad's First Legal Document, The Darwin Press, Princeton 2004.

33. Jones A., The Dotting of a Script and the Dating of an Era: The Strange Neglect of PERF 558, "Islamic Culture" 72 (4/1998), pp. 95-103.

34. Jones A., Orality and Writing in Arabia [in:] J. D. McAuliffe (ed.), Encyclopaedia of the Qur'an, Brill, Leiden - Boston 2003, Vol. 3, pp. 591-593.

35. Jones A., The Word Made Visible: Arabic Script and the Committing of the Qur'an to Writing, [in:] Ch. F. Robinson (ed.), Texts, Documents and Artefacts. Islamic Studies in Honour of D.S. Richards, Brill, Leiden 2003, pp. $1-16$.

36. Kassis H. E., Concordance to the Quran, University of California Press, Berkeley - Los Angeles - London 1983.

37. Kościelniak K., Chrześcijańskie piśmiennictwo arabskie przed Mahometem i jego wptyw na islam, "Analecta Cracoviensia” 35 (2003), pp. 329-343.

38. Loveday H., Islamic Paper. A Study of the Ancient Craft, Archetype Publications, no place 2001.

39. MacDonald M. C. A., Reflections on the Linguistic Map of pre-Islamic Arabia, "Arabian Archeology and Epigraphy" 11 (2000), pp. 28-79.

40. MacDonald M. C. A., Literacy in an Oral Environment, [in:] P. Bienkowski, Ch. Mee, E. Slater (ed.), Writing and Ancient Near Eastern Society. Papers in Honour of Alan R. Millard, T \& T Clark, New York London 2005, pp. 45-114.

41. MacDonald M. C. A., Ancient Arabia and the Written Word, [in:] idem (ed.), The Development of Arabic as a Written Language, Supplement to the Proceedings of the Seminar for Arabian Studies Volume 40, Archaeopress, Oxford 2010, pp. 5-27.

42. Nenmé L., A Glimpse of the Development of the Nabatean Script into Arabic based on Old and New Epigraphic Material, [in:] M. C. A. Macdonald (ed.), The Development of Arabic as a Written Language, Supplement to the Proceedings of the Seminar for Arabian Studies Volume 40, Archaeopress, Oxford 2010, pp. 47-88. 
43. Oseini Z. I., An Examination of Al-Hajjāj b. Yūsuf al-Thaqafís Major Policies, "Islamic Studies" 27 (4/1988), pp. 317-327.

44. Osman Gh., Pre-Islamic Arab Converts to Christianity in Mecca and Medina: An Investigation into the Arabic Sources, "The Muslim World" 95 (2005), pp. 67-80.

45. Overlaet B., MacDonald M., Stein P., An Aramaic-Hasaitic bilingual inscription from a monumental tomb at Mleiha, Sharjah, UAE, "Arabian Archaeology \& Epigraphy" 27 (1/2016), pp. 127-142.

46. Powell B. B., Writing. History and Theory of the Technology of Civilization, Wiley-Blackwell, Malden, Mass. 2012.

47. Prochwicz-Studnicka B., The Origins of High Significance of Writing in Arab-Muslim Culture, "Anthropos", 113 (2018), s. 217-233.

48. RAGHeB Y., Les premiers documents arabes de l'ère musulmane, "Travaux Et Mémoires" 17 (2013), pp. 679-726.

49. Restö J., The Arabs in Antiquity. Their History from the Assyrians to the Umayyads, Routledge Curzon, London - New York 2003.

50. Rogers R. W., Cuneiform Parallels to the Old Testament, Eaton \& Mains, New York 1912.

51. SAdeghi B., Goudarzi M., San ' $\bar{a}$ ' I and the Origins of the Qur'ān, "Der Islam" 87 (1-2/2012), pp. 1-129.

52. Sadeghi B., Bergmann U., The Codex of a Companion of the Prophet and the Qur'an of the Prophet, "Arabica” 57 (4/2010), pp. 343-436.

53. Sснеск F. R., Szlak mirry i kadzidła. Od Arabii do Rzymu - śladem antycznych kultur, tłum. J. Danecki, PIW, Warszawa 1998 [original title: Weichrauchstrasse von Arabien nach Rom - auf den Spuren antiker Weltkulturen, Bergisch Gladbach, Lübbe 1995.]

54. Schoeler G., The Genesis of Literature in Islam. From the Aural to the Read, Sh. M. Toorawa (trans.), Edinburgh University Press, Chippenham 2011.

55. ShahīD I., Byzantium and the Arabs in the Sixth Century, Vol. 2, Part 2. Economic, Social, and Cultural History, Dumbarton Oaks Research Library and Collection, Washington, D.C. 2010.

56. Shahìd I., Byzantium and the Arabs in the Sixth Century, Vol. 1, Part 1. Political and Military History, Dumbarton Oaks Research Library and Collection, Washington, D.C. 1995.

57. Sima A., Die hasaitischen Inschriften [in:] N. Nebes (ed.), Neue Beiträge zur Semitistik. Erstes Arbeitstreffen der Arbeitsgemeinschaft Semitistik 
in der Deutschen Morgenländischen Gesellschaft vom 11. bis 13. September 2000 an der Friedrich-Schiller-Universität Jena, Harrassowitz Verlag, Wiesbaden 2002, pp. 167-200.

58. Sijpesteijn P. M., Paleography, [in:] K. Versteegh (general ed.), Encyclopedia of Arabic Language and Linguistics, Brill, Leiden - Boston 2008, Vol. 3, pp. 513-524.

59. Testen D., On the Arabic of the 'En 'Avdat Inscription, "Journal of Near Eastern Studies” 55 (4/1996), pp. 281-292.

6o. Toorawa Sh. M., Ibn Abī Țāhir TTayfūr and Arabic Writerly Culture. A Ninth-Century Bookman in Baghdad, Routledge Curzon, London New York 2005. 